\title{
Abundance and habitat preferences of the short-beaked common dolphin Delphinus delphis in the southwestern Mediterranean: implications for conservation
}

\author{
A. Cañadas ${ }^{1, *}$, P. S. Hammond ${ }^{2}$ \\ ${ }^{1}$ ALNITAK \& SEC, Nalón 16, 28240 Hoyo de Manzanares, Madrid, Spain \\ ${ }^{2}$ Sea Mammal Research Unit, Gatty Marine Laboratory, University of St Andrews, St Andrews, Fife KY16 8LB, UK
}

\begin{abstract}
The Mediterranean sub-population of short-beaked common dolphin is believed to have suffered a steep decline in the Mediterranean in recent years, and in 2003 it was listed as endangered in the IUCN Red List of Threatened Species. Effective conservation will depend critically on our understanding of the relationship between the species and its habitats. The Alborán Sea is believed to be the most important remaining Mediterranean habitat for this species, and thus constitutes a vital source of information for the development of conservation measures. We used spatial modelling to estimate the abundance and explore the habitat use of common dolphins in this area, examining regional, seasonal and interannual variations, as well as the influence of biological factors such as presence of calves, interspecific relationships and behaviour. From 1992 to 2004, $37385 \mathrm{~km}$ of non-systematic line transects generated 738 sightings in a $19189 \mathrm{~km}^{2}$ study area. The point estimate of abundance was 19428 (95\% CI = 15277 to 22 804) dolphins. Seasonal and geographical variations in abundance were detected, with higher average density in summer than in winter, and in the Western Alborán Sea than in the east Gulf of Vera, which has different physical/environmental characteristics. No overall trend in abundance was observed in the Alborán area. However, a decline was observed in the Gulf of Vera, with a summer density 3-fold lower in the period from 1996 to 2004 than in 1992 to 1995. A potential link of this decline with prey depletion due to the exponential growth of aquaculture in the area is discussed. Clear differences in habitat use were also found when examining the influence of biological factors. In particular, groups with calves and groups that were feeding preferred more coastal waters. This result could have important implications for the development of conservation measures for this species in the Mediterranean.
\end{abstract}

KEY WORDS: Common dolphin · Mediterranean · Generalized Additive Models · GAMs · Abundance $\cdot$ Trends $\cdot$ Habitat use $\cdot$ Alborán Sea

Resale or republication not permitted without written consent of the publisher

\section{INTRODUCTION}

Short-beaked common dolphins Delphinus delphis (hereafter referred to as 'common dolphins') in the Mediterranean appear to have suffered a steep decline over recent decades (UNEP/IUCN 1994, Aguilar et al. 1995, Bearzi et al. 2003), although no reliable time series of abundance data exist. In 2003, the Mediterranean common dolphin subpopulation, as defined by the IUCN, was listed as endangered in the International Union for the Conservation of Nature and Natural Resources, World Conservation Union (IUCN) Red List of Threatened Species, based on criterion A2, which refers to a $50 \%$ decline in abundance over the last 3 generations (35 to $45 \mathrm{yr}$ ), the causes of which 'may not have ceased or may not be understood or may not be reversible' (www.iucnredlist.org/search/ details.php/41762/summ). Possible causes of this de- 
cline include: by-catch, depletion of food resources due to overfishing, toxic pollution or a combination of these factors (Bearzi et al. 2003).

The IUCN/Species Survival Commission (SSC) Cetacean Specialist Group has recommended that studies to 'investigate the distribution, abundance, population structure, and factors threatening the conservation of short-beaked common dolphins in the Mediterranean and Black Seas' be intensified (Reeves et al. 2003). ACCOBAMS (the Agreement for the Conservation of Cetaceans in the Black Sea, Mediterranean Sea and contiguous Atlantic Area under the UN Convention for Migratory Species) commissioned the development of a Conservation Plan for the common dolphin in the Mediterranean Sea (Bearzi et al. 2004). In its Implementation Priorities (ACCOBAMS 2002) proposed that areas containing critical habitat for priority species should be identified, in which pilot conservation and management projects should be developed and implemented immediately. In the Conservation Plan, areas considered to be of special conservation value for common dolphins (Areas of Conservation Importance, ACIs), and therefore potential marine protected areas (MPAs) were selected based on the - admittedly limited - knowledge of the distribution and frequency of occurrence of common dolphins in the Mediterranean.

This knowledge-as well as information on the scale and relative importance of actual or potential anthropogenic threats to dolphins and priorities of possible mitigation measures - is lacking, but must be increased quickly if effective conservation actions are to be implemented (Bearzi et al. 2004). Most importantly, baseline population abundance and information on distribution is needed to put any identified threats to common dolphins into context and to establish priority conservation and mitigation measures. Monitoring distribution and abundance is necessary to determine whether these measures are fulfilling established conservation objectives.

In general, MPAs or marine reserves may offer a solution to some of the challenges involved in management of the marine environment. They allow conservation efforts or management actions to focus at a geographical scale that is more tangible for the general public. In this way, marine reserves can allow the organisation of human activities through zoning (e.g. 'no take' zones and buffer zones), at the same time as preserving the natural attributes of the region and its value as a tool for public awareness and education.

One of the ACIs selected in the ACCOBAMS Conservation Plan for common dolphins in the Mediterranean Sea is the Alborán Sea (see Fig. 1), largely because the encounter rates for this species in this area are the highest in the whole Mediterranean basin
(Bearzi et al. 2004). Genetic studies of Mediterranean common dolphins found that animals in the Alborán Sea are genetically more closely related to those in the northeast Atlantic than to those in the eastern Mediterranean and may constitute a different population from the latter (Natoli 2005). This structuring of the population may have important implications for conservation.

The only large-scale cetacean survey in the western part of the Mediterranean Sea was carried out in 1991 to 1992 (Forcada \& Hammond 1998). The latter study estimated abundance of common dolphins in the Alborán Sea as follows: 14736 common dolphins (95\% $\mathrm{CI}=6923$ to 31 366; coefficient of variation $[\mathrm{CV}]=0.40$ ) in an area of $90670 \mathrm{~km}^{2}$. The only other estimate of abundance in the Mediterranean is for a small inshore area in the Ionian Sea, based on photo-identification of around 100 animals (Bearzi et al. 2003).

Previous studies in the northeastern Alborán Sea examined the influence of depth and slope on the distribution of common dolphins (Cañadas et al. 2002) but without any attempt to predict distribution based on the described relationships. In the present study we analyse a much more extensive dataset on this species in the whole northern Alborán Sea to model regional, seasonal and inter-annual variation in abundance and habitat preferences, and to map model predictions to inform spatial aspects of conservation and management. To estimate abundance we use model-based line-transect sampling methods (Hedley et al. 1999, Marques 2001), recently applied to common bottlenose dolphins Tursiops truncatus in this area (Cañadas \& Hammond 2006).

Distribution and habitat use of a species with complex ecology, social structure and behaviour are very likely influenced not only by 'extrinsic' (i.e. abiotic and biotic environmental) factors but also by 'intrinsic' factors (e.g. reproductive status, feeding strategies, behaviour, inter-specific relationships). Understanding these influences and the inter-relationships among them will greatly improve our understanding and interpretation of the species' ecology as well as improving our ability to develop targeted and more effective mitigation and conservation measures. In the present paper, we begin to explore the habitat preferences of common dolphins in the study area, examining 'intrinsic' factors such as presence of calves, interspecific relationships and behaviour, thereby building on the work of Cañadas et al. (2002, 2005). This is the first time these methods have been used in such an investigation of a cetacean species.

We discuss the implications of the results for the conservation of common dolphins in the Mediterranean Sea, especially with respect to bycatch in fishing nets and the establishment of MPAs. 


\section{MATERIALS AND METHODS}

Data collection. Survey area, survey design and searching effort: Surveys were conducted during the period 1992 to 2004 by the RV 'Toftevaag'. From 1992 to 1999, surveys were only conducted in the waters off Southern Almería $\left(4232 \mathrm{~km}^{2}\right)$, and the Gulf of Vera $\left(6164 \mathrm{~km}^{2}\right)$; however during 1993 and 1994, surveys were conducted only in the Gulf of Vera, and in 1999 only off Southern Almería (Fig. 1). Between 2000 and 2004, the whole northern section of the Alborán Sea and the Gulf of Vera was surveyed, an area of $19189 \mathrm{~km}^{2}$ (Fig. 1). In 2003 and 2004, the RV 'Else' also
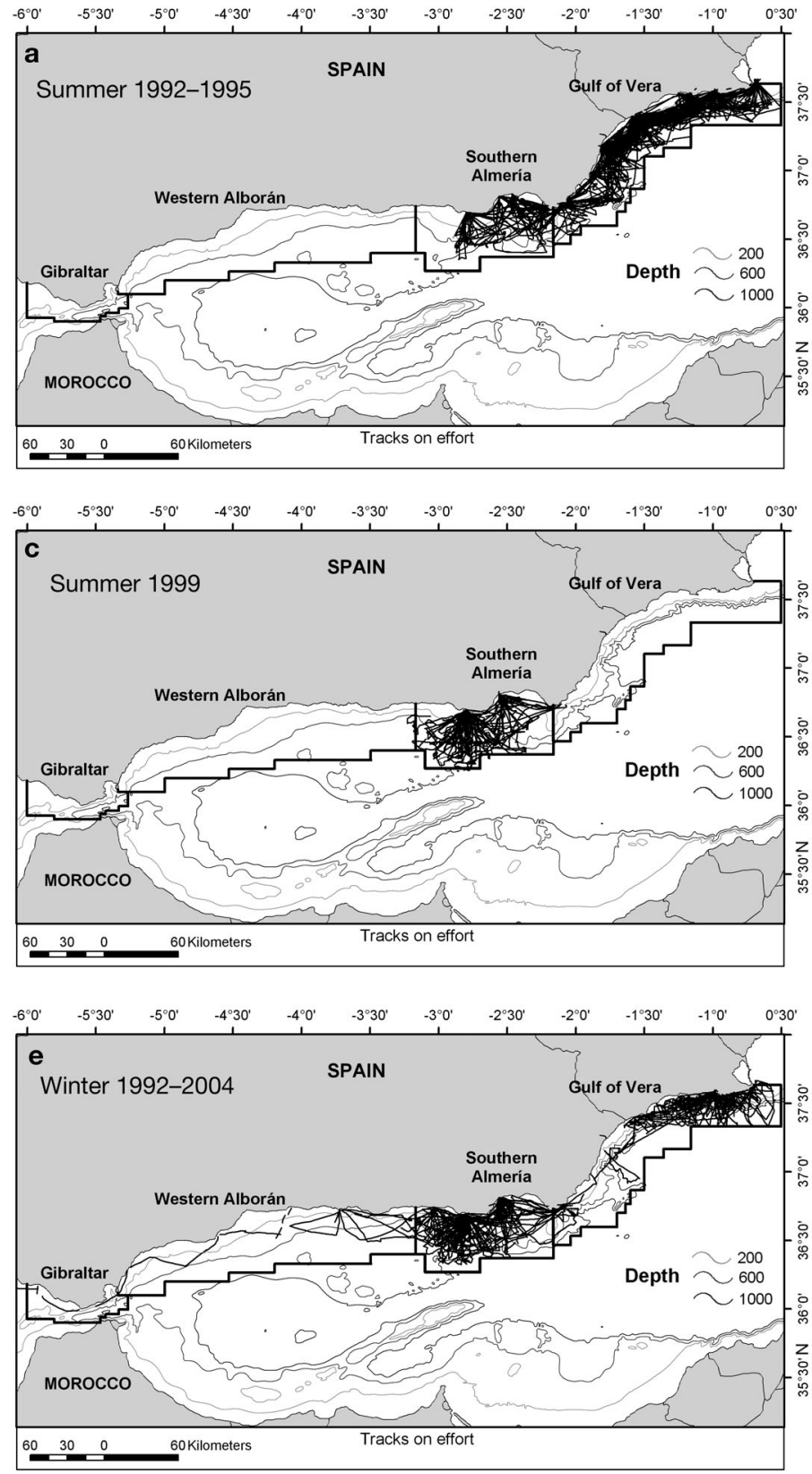

surveyed the region of Murcia (northern Gulf of Vera). From 1992 to 1998 surveys were made during March and April and from June to September. The study area was sampled in January, March, June to September and November from 1999 to 2004. For a comparative analysis the study area was divided into 3 major areas: Gulf of Vera, Southern Almería and Western Alborán Sea (Fig. 1).

The study used line transect sampling methods, but transects did not follow a systematic design because of logistic limitations on vessel operation (relatively slow cruising speed, high dependence on weather conditions and the need to return to port every night).
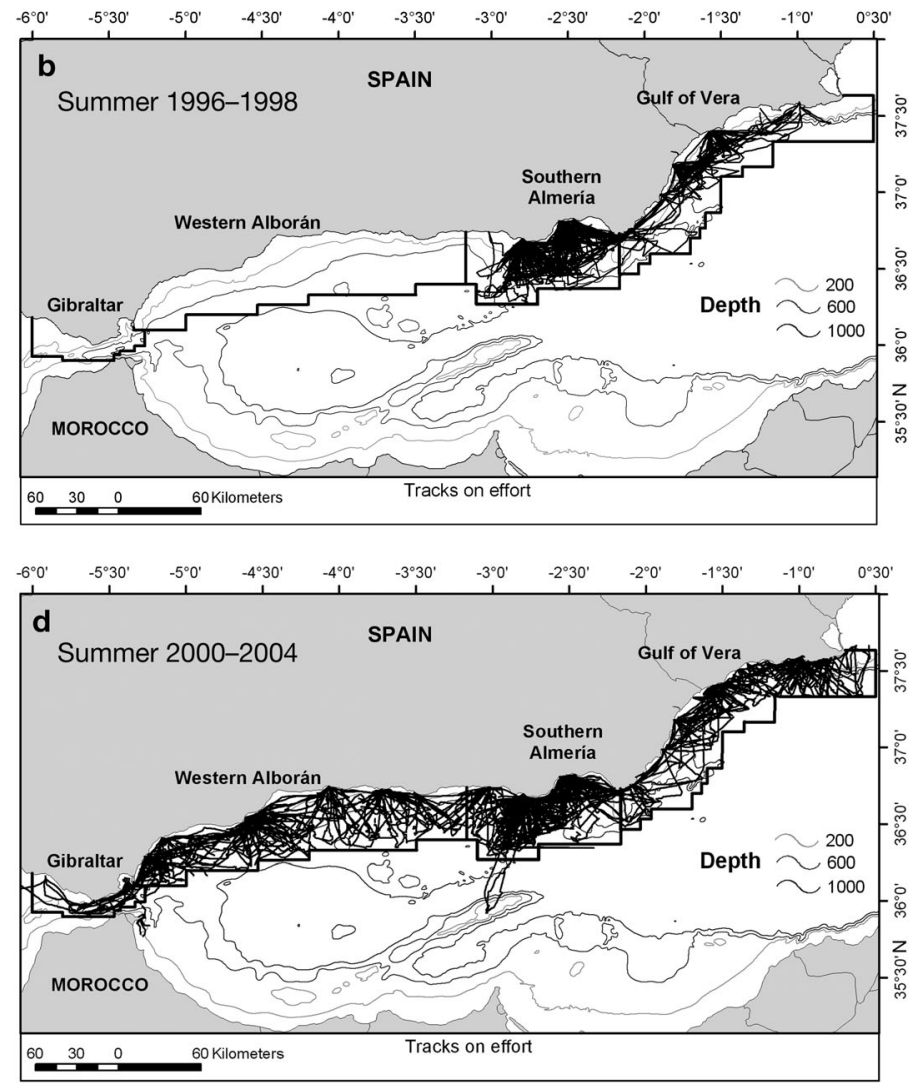

Fig. 1. Tracklines on effort during the summer months from (a) 1992-1995, (b) 1996-1998, (c) 1999, (d) 2000-2004 and (e) winter months from 1992-2004. Thick, straight solid lines represent the study area 
Instead, cruise tracks were designed to cross depth contours and to cover as much of the area as possible. Both ships had two (non-independent) observation platforms, one on the crow's nest with an eye height of $11 \mathrm{~m}$ and another on deck with an eye height of $2.5 \mathrm{~m}$, and a cruising speed of 5 knots, $\mathrm{kn}\left(9.3 \mathrm{~km} \mathrm{~h}^{-1}\right)$. It was not possible to implement double platform methodology to estimate the proportion of animals or clusters missed on the transect line (e.g. Borchers et al. 2002, Hammond et al. 2002). Sighting effort was categorized into 4 'effort types' according to sea state and whether or not swell conditions allowed a trained observer in the crow's nest: 1 (sea state 1 on the Douglas scale and 1 observer in the crow's nest), $1 \mathrm{~S}$ (sea state 1 and no crow's nest watch $-\mathrm{S}$ indicating swell), 2 (sea state 2 with crow's nest watch) and $2 \mathrm{~S}$ (sea state 2 and no crow's nest watch).

Sightings data: When an animal or group of animals was detected, immediate data were taken, including angle from the detected group to the trackline, estimated radial distance of the detected group to the ship, initial behaviour and direction of travel (if any). Before 2001, angle boards were not used and all angles were rounded to the nearest 5 or $10^{\circ}$. From 2001 onwards, angles were measured with an angle board on the crow's nest or on the bridge, avoiding any rounding. Distances were always estimated by the naked eye. No distance estimation experiments were carried out before or during the surveys. Animals were approached to confirm species composition and group size, which were assessed several times during the encounter. The number of calves and the estimated number of animals in any subgroups were also recorded. Any changes in group composition (subgroups joining or leaving) were recorded to ensure that the best estimate of group size related to the group initially sighted.

Observed behaviour was recorded in 5 categories: feeding-foraging, resting, socialising, travelling (slow: $<2 \mathrm{kn}$; moderate: 2 to $4 \mathrm{kn}$; fast: $>4 \mathrm{kn}$, all estimated by comparison with the speed of the survey vessel) and milling, according to definitions given in Cañadas \& Hammond (2006).

Environmental data: Data on physical and environmental features were collated for the entire study area. Depth and slope of the seabed were extracted from nautical charts of the Hydrographic Institute of the Spanish Navy and supplemented by more detailed measurements taken on surveys since 2001. Sea surface temperature (SST) and chlorophyll concentration (chl) data were extracted from the ascii data of satellite images obtained from the Center for Reception, Processing, Archiving and Dissemination of Images of Earth Observation Data (CREPAD) service of the INTA (Spanish Space Agency), which consisted of NOAA Advanced Very High Resolution Radiometer (AVHRR) images for SST (1998 to 2004) and SeaWIFS (sea-viewing wide field-of-view sensor) images for chl (2000 to 2004) with a pixel resolution of $2 \mathrm{~km}^{2}$. Averages for both SST and chl were calculated for summer and for winter months, for all data available and by groups of years according to the datasets analyzed (see 'Data organisation'). Averages for years in which data were available were used as proxies for typical conditions in earlier years when no SST or chl data were available. Temporal variability in SSTwas estimated by calculating the standard deviation of the daily SST.

The number of ships and measurements of ship noise were recorded every 20 min during survey effort. Encounter rates of trawlers were calculated as the number of trawlers encountered divided by the number of sampling events.

Data analysis. Data organisation: The study area was divided into 1827 grid cells, with a cell resolution of 2 min latitude by 2 min longitude. Each grid cell was characterised by geographical and environmental covariates (Table 1).

Data were stratified into 2 seasons: summer (defined as June to September) and winter (defined as October to May). Winter data were pooled over years (1992 to 2004) because of small sample size and were only considered for the waters off Southern Almería and Almería-Vera. The summer data were organised at 5 spatial levels and different time periods (Table 2). The smaller datasets (Western Alborán, Southern Almería and Gulf of Vera) were used to examine differences in abundance estimates in small areas analysed separately or extracted from the analysis of a larger area.

All on effort transects were divided into small segments (average $2.7 \mathrm{~km}$, minimum $0.4 \mathrm{~km}$, maximum $3.9 \mathrm{~km}$ ) of homogeneous effort type. It was assumed that there would be little variability in physical and environmental features within segments. Each segment was assigned to a grid cell based on the midpoint of the segment, and values of covariates for each grid cell were associated with the segment.

Spatial modelling of abundance: For model-based abundance estimation, 5 steps were followed, as in Cañadas \& Hammond (2006): (1) a detection function was estimated from the line transect data and any covariates that could affect detection probability; (2) the number of groups in each segment was estimated through the Horvitz-Thompson estimator (Horvitz \& Thompson 1952); (3) abundance of groups was modelled as a function of geographical and environmental covariates; (4) group size was modelled as a function of detection probabilities and covariates; (5) abundance of animals was estimated in each grid cell as the product of model predictions from steps 3 and 4 .

Estimation of detection function: Four different detection functions were obtained: for each ship and 
Table 1. Variables, and groups of variables, associated to the grid cells and used in the models

\begin{tabular}{|c|c|}
\hline $\begin{array}{l}\text { Variables } \\
\text { and groups }\end{array}$ & Definition \\
\hline \multicolumn{2}{|l|}{ Geographic } \\
\hline lat & Latitude \\
\hline lon & Longitude \\
\hline \multicolumn{2}{|c|}{ Physiographic (depth) } \\
\hline depth & Depth \\
\hline logdepth & Logarithm of depth \\
\hline distcoast & Distance from coast \\
\hline logdistcoast & Logarithm of distance from coast \\
\hline dist200 & Distance from the $200 \mathrm{~m}$ isobath \\
\hline dist1000 & Distance from the $1000 \mathrm{~m}$ isobath \\
\hline \multicolumn{2}{|c|}{ Physiographic (bottom) } \\
\hline cvdepth & Coefficient of variation of depth \\
\hline sddepth & SD of depth \\
\hline slope & Slope $\left(\mathrm{m} \mathrm{km}^{-2}\right)$ \\
\hline $\mathrm{ci}$ & $\begin{array}{l}\text { Contour index ((max. depth-min. } \\
\text { depth) } \times 100 / \text { max. depth) }\end{array}$ \\
\hline \multicolumn{2}{|c|}{ Oceanographic (echo-sounder) } \\
\hline ersl1 & Encounter rate of first scattering layer \\
\hline lowersl1v & Lower limit of first scattering layer in summer \\
\hline ersl2 & Encounter rate of second scattering layer \\
\hline fishpelv & Encounter rate of pelagic fish in summer \\
\hline fishv & Encounter rate of all fish in summer \\
\hline \multicolumn{2}{|c|}{ Oceanographic (satellite image) } \\
\hline cavv & Mean summer chlorophyll concentration \\
\hline cavi & Mean winter chlorophyll concentration \\
\hline cav & Mean annual chlorophyll concentration \\
\hline tavv & Mean summer SST \\
\hline $\operatorname{tav}$ & Mean annual SST \\
\hline tdsv & SD of summer SST \\
\hline tds & SD of annual SST \\
\hline \multicolumn{2}{|c|}{ Anthropogenic } \\
\hline distpesq & Distance from fishing ports \\
\hline $\operatorname{acshv}$ & Index of summer acoustic pollution \\
\hline ertr & Encounter rate of trawlers \\
\hline
\end{tabular}

for 2 different levels of effort: with or without mast watch. For the 'Else', all dolphin species (common, bottlenose, and striped dolphins Stenella coeruleoalba) were included in the datasets for estimating the detection functions to increase the sample size. For effort types $1 \mathrm{~S}$ and $2 \mathrm{~S}$, a total of 53 sightings were used. For effort types 1 and 2, 70 sightings were used.

For the 'Toftevaag', common and striped dolphins (including mixed species schools) were used to estimate the detection function. For Effort Types 1S and $2 \mathrm{~S}$, a total of 334 sightings were used. For Effort Types 1 and 2, 1361 sightings were used.

Angle data prior to 2001 and all distance data were subjected to a smearing procedure to reduce the effects of rounding in distances and/or angles to favoured values by selecting at random a value of distance or angle within a 'smearing sector' centred on the recorded position (Buckland et al. 2002). The parameters for the smearing procedure were chosen after visual inspection of the data.

The software DISTANCE 5.0 release 1 (Thomas et al. 2005) was used to estimate the detection function, using the multiple covariate distance sampling (MCDS) method (Marques 2001, Thomas et al. 2002). The perpendicular distance data were right truncated prior to the analysis, following the recommendations of Buckland et al. (2001). All covariates given in Table 3 and combinations of them were incorporated. Models were fitted starting with single covariates and continuing with combinations of 2, 3 and 4 covariates. The selection of the best detection function was made using Akaike's Information Criterion (AIC).

Estimation of number of groups per segment: The response variable used to formulate a spatial model of abundance of groups was the estimated number of groups $(\hat{\mathrm{N}})$ in each segment, estimated

Table 2. Organisation of datasets for analysis

\begin{tabular}{|c|c|c|c|}
\hline Area & Whole dataset & Sub-datasets & Reason \\
\hline $\begin{array}{l}\text { Alborán - Almería - } \\
\text { Vera }\end{array}$ & $2000-2004$ & $\begin{array}{l}2000-2002 \\
2003-2004\end{array}$ & Slight increase of encounter rates during the last $2 \mathrm{yr}$ \\
\hline Almería - Vera & $\begin{array}{l}1992-2004 \\
1996-1998 \\
2000-2004 \\
1996-2004\end{array}$ & $1992-1995$ & $\begin{array}{l}\text { Fluctuations in encounter rates. Sample size insufficient to } \\
\text { further stratify in 2000-2002 and 2003-2004 }\end{array}$ \\
\hline Western Alborán & $2000-2004$ & $\begin{array}{l}2000-2002 \\
2003-2004\end{array}$ & Slight increase of encounter rates during the last $2 \mathrm{yr}$ \\
\hline Southern Almería & $1992-2004$ & $\begin{array}{c}1996-1998 \\
1999\end{array}$ & $\begin{array}{l}\text { Reasons for considering } 1999 \text { alone are given in Cañadas } \\
\text { et al. (2002). Other sub-datasets equivalent to Almería- } \\
\text { Vera. Insufficient sample size for 1992-1995 }\end{array}$ \\
\hline Gulf of Vera & $1992-2004$ & $\begin{array}{l}2000-2004 \\
1992-1995 \\
1996-2004\end{array}$ & Strong decrease in encounter rates since 1996 \\
\hline
\end{tabular}


Table 3. Covariates incorporated in modelling the detection function, indicating whether treated as a continuous variable or as a factor, and the levels used when treated as a factor. Douglas: Douglas scale

\begin{tabular}{|lll|}
\hline Covariate & Type & Levels \\
\hline Group size & Continuous & \\
Species (for RV Else only) & Continuous (logarithm) & \\
Observer & Factor & 2 levels: common-striped dolphins; bottlenose-Risso's dolphins \\
Year & Factor & 2 levels: mast ; deck \\
Cue & Factor & 4 levels: 1992-1994; 1995-1997; 1998-2000; 2001-2002 \\
Sea state & Factor & 2 levels: fin-back (less conspicuous); other (conspicuous) \\
Time (hours from sunrise) & Factor & 3 levels: 0; $1 ; 2$ Douglas \\
& Continuous & 2 levels: 0-1; 2 Douglas \\
\hline
\end{tabular}

through the Horvitz-Thompson estimator (Horvitz \& Thompson 1952):

$$
\hat{\mathrm{N}}_{i}=\sum_{j=1}^{n_{i}} \frac{1}{\hat{\mathrm{p}}_{i j}}
$$

where $n_{i}$ is the number of detected groups in the $i$ th segment, and $\hat{p}_{i j}$ is the estimated probability of detection of the $j$ th group in segment $i$. The probability of detection was obtained from the detection function fitted to the data for each ship and effort type.

Modelling abundance of groups and group size: The potential explanatory covariates used are listed in Table 1. Interactions between covariates were investigated.

The abundance of groups was modelled using a Generalized Additive Model (GAM) with a logarithmic link function. Due to over-dispersion in the data, a quasi-Poisson error distribution was used, with variance proportional to the mean, and using the effective searched area of each segment as an offset. The general structure of the model was:

$$
\hat{\mathrm{N}}_{i}=\exp \left[\ln \left(a_{i}\right)+\theta_{0}+\sum_{k} f_{k}\left(z_{i k}\right)\right]
$$

where the offset $a_{i}$ is the search area for the $i$ th segment (calculated as the length of the segment multiplied by twice the truncation distance), $\theta_{0}$ is the intercept, $f_{k}$ are smoothed functions of the explanatory covariates, and $z_{i k}$ is the value of the $k$ th explanatory covariate in the $i$ th segment.

Models were fitted using package 'mgcv' v. 1.0-5 for $\mathrm{R}$ (Wood 2001). Automated model selection by a stepwise procedure was not yet implemented in the version of $\mathrm{R}$ used (2.0.0) (available from http://cran. r-project.org). Therefore, manual selection of the models was done using 3 indicators, as described in Cañadas \& Hammond (2006): (1) the GCV (General Cross Validation score; Wood 2001); (2) the percentage of deviance explained; and (3) the probability that each variable is included in the model by chance. In all models, a visual inspection of the residuals was also made, especially to look for trends.
Group size was also modelled using a GAM with a logarithmic link function. The response variable was the number of individuals of common dolphins counted in each group $\left(s_{j}\right)$ and, given the large overdispersion due to the wide range of group sizes (1 to 1000), a quasi-Poisson error distribution was used, with the variance proportional to the mean. The detection probability was included as a linear predictor (Borchers \& Burt 2001) in order to avoid the bias introduced by the selective detection of larger groups at larger distances or by other covariates affecting the detection of the groups. Therefore, in the case of mixed groups, the response variable included only the number of common dolphins in the group, but the detection probability included as a linear predictor was that of the group as a whole. The general structure of the model was:

$$
\mathrm{E}\left(s_{j}\right)=\exp \left[\hat{g}_{j}(y, v)+\theta_{0}+\sum_{k} f_{k}\left(z_{j k}\right)\right]
$$

where $\hat{g}_{j}(y, v)$ is the conditional detection probability of the expected (E) size of the $j$ th group given that it was detected at perpendicular distance $y$ and with covariates $v, \theta_{0}$ is the intercept, $f_{k}$ are smoothed functions of the explanatory covariates, and $z_{j k}$ is the value of the $k$ th explanatory covariate in the $j$ th group. Manual selection of the models was done following the same criteria described for the models of abundance of groups.

Estimation of abundance: Abundance of groups and of group size were predicted by the final models in all grid cells of the study area. The estimated abundance of animals for each grid cell was calculated as the product of its predicted abundance of groups and its predicted group size. The point estimate of total abundance was obtained by summing the abundance estimates in all grid cells over the study area.

Estimation of variance: The whole analytical process was applied to 400 non-parametric bootstrap resamples, using day as the resampling unit, to obtain the coefficient of variation and percentile based $95 \%$ confidence intervals. For each model in each bootstrap 
resample, the degree of smoothing of each model term was chosen by the 'mgcv' package, thus incorporating some model selection uncertainty in the variance. It was not possible to calculate a single CV for the abundance estimate for each dataset analysed because there were 4 different detection functions applied to the data, according to ship and effort type. Instead, for each dataset, the delta method (Seber 1982) was used to combine the $\mathrm{CV}$ from the bootstrap with the $\mathrm{CV}$ from each detection function used, giving a range of final CVs.

Random and responsive movement: The average searching speed of both ships was $5 \mathrm{kn}$, which is slow compared to most line transect surveys for cetaceans. Because random movement of animals leads to increasing bias as the ratio of animal speed to ship speed increases (Hiby 1982), we investigated whether this was a problem in our data. An average speed for each behavioural category was assigned to each sighting: $0 \mathrm{kn}$ for socialising, milling, feeding and resting; $1 \mathrm{kn}$ for travelling slowly; $3 \mathrm{kn}$ for travelling at moderate speed and $5 \mathrm{kn}$ for travelling fast.

We also investigated whether responsive movement had occurred before detection by calculating the ratio of animals or groups with swimming direction relative to the transect line in the third quadrant (Q3: 180 to $270^{\circ}$ ) compared to the first quadrant (Q1: 0 to $90^{\circ}$ ), following Palka \& Hammond (2001). The ratio between these quadrants was evaluated using a chi-square test, to see if there was any evidence of attraction (Q3:Q1 > 1) or avoidance $(\mathrm{Q} 3: \mathrm{Q} 1<1)$.

Habitat preference: Differences in habitat preference were explored by stratification in terms of (a) areas, (b) seasons (summer = June to September; winter = October to May), (c) years, (d) behavioural categories, (e) groups with or without calves; and (f) single species groups and mixed species groups with striped dolphins. Animals were classified as calves when their body size was less than or equal to $75 \%$ the body size of the accompanying adults. For (d), (e) and (f), summer data only were pooled over years.

\section{RESULTS}

\section{Effort and sightings}

A total of $37385 \mathrm{~km}$ was surveyed on effort between 1992 and 2004 in the study area during summer (June to September). Of these, $17688 \mathrm{~km}$ were surveyed in the Gulf of Vera, $17133 \mathrm{~km}$ off Southern Almería, and $6724 \mathrm{~km}$ between 2000 and 2004 in the western portion of the Alborán Sea (including the Strait of Gibraltar). Fig. 1a-d shows the searching effort for 1992-1995, 1996-1998, 1999 and 2000-2004, respec- tively (periods used in analysis). A total of 762 sightings of common dolphins within the truncation distance (see 'Detection function') was made while searching on effort during these months. A total of $7533 \mathrm{~km}$ was surveyed on effort during winter (October to May) from 1992 to 2004, of which $3224 \mathrm{~km}$ were surveyed in the Gulf of Vera, and $4309 \mathrm{~km}$ off Southern Almería (Fig. 1e). A total of 96 sightings of common dolphins within the truncation distance were made during these months.

\section{Random and responsive movement}

There were 707 sightings of common dolphins on effort, for which data on initial behaviour, and therefore estimated speed, were available. The average estimated speed of the dolphins was $2.2 \mathrm{kn}$ ( $\mathrm{SE}=$ $0.08 \mathrm{kn}$ ); the ratio of dolphin speed to ship speed was therefore 0.44 , below the value of 0.5 considered as problematic (Hiby 1982, Palka \& Hammond 2001). We conclude that any bias as a result of random movement is likely to be small.

For investigation of possible responsive movement, data on initial heading relative to the transect line were available for 497 sightings of common dolphins. Of these, 142 groups (28.6\%) were stationary and not heading in any direction. For the remaining sightings, the ratio $Q 3: Q 1$ was 1.17 , which is not significantly different from one $\left(\chi^{2}=0.95, \mathrm{df}=1, \mathrm{p}>0.05\right)$, suggesting no responsive movement of the animals before detection.

\section{Detection function}

RV 'Else': Effort Types 1 and 2. Perpendicular distance was truncated at $1500 \mathrm{~m}$, discarding $13.2 \%$ of the data with the largest distances, leaving 64 sightings for analysis. The best fitting model was a halfnormal key function with cosine series expansion and one adjustment term. Three covariates were selected: position of the observer, sea state and group size (Table 4, Fig. 2).

RV 'Else': Effort Types 1S and 2S. Perpendicular distance was truncated at $900 \mathrm{~m}$, discarding $8.6 \%$ of the data, leaving 46 sightings for analysis. The best fitting model was a hazard-rate key function with no series expansion and adjustment terms. Only 1 covariate was selected (probably due to the small sample size): group size (Table 4, Fig. 2).

RV 'Toftevaag': Effort Types 1 and 2. Perpendicular distance was truncated at $3600 \mathrm{~m}$, discarding $2.9 \%$ of the data with the largest distances, leaving 1321 sightings for analysis. The best fitting model was a 
Table 4. Results for the 4 detection functions. The following information is given for each function: type of model; truncation (trunc) distance (\# obs: resulting number of observation after truncation); p, probability of detection (SE); ESW, effective strip width (SE); \%CV, coefficient of variation of $\mathrm{p}$ and ESW; levels of the variables selected in the models, their coefficients and their SE. For the variables, OBS: position of the observer, CLUSTER SIZE: group size, SEA: sea state, LOGCLSIZE: logarithm of group size, CUE: cue for detection, TIME: hours since sunrise. The remaining level for each factor is included in the intercept

\begin{tabular}{|c|c|c|c|c|c|c|c|c|}
\hline Dataset & Model & $\begin{array}{c}\text { Trunc } \\
\text { distance } \\
\text { (\# obs.) }\end{array}$ & $\begin{array}{c}\mathrm{p} \\
(\mathrm{SE})\end{array}$ & $\begin{array}{l}\text { ESW } \\
\text { (SE) }\end{array}$ & $\% \mathrm{CV}$ & Variables & Coefficient & SE \\
\hline $\begin{array}{l}\text { RV 'Else' } \\
\text { Effort Types } \\
1 \& 2\end{array}$ & Half-normal & $\begin{array}{c}1500 \mathrm{~m} \\
(64)\end{array}$ & $\begin{array}{c}0.256 \\
(0.037)\end{array}$ & $\begin{array}{l}388.75 \\
(56.70)\end{array}$ & 14.78 & $\begin{array}{l}\text { Intercept of the scale parameter } \\
\text { Level D of factor covariate OBS } \\
\text { Covariate CLUSTER SIZE } \\
\text { Level } 0 \text { of factor covariate SEA } \\
\text { Level } 1 \text { of factor covariate SEA } \\
\text { Cosine adjustment term of order } 2\end{array}$ & $\begin{array}{c}371.8 \\
-0.9488 \\
0.0373 \\
0.3636 \\
-0.4702 \\
20.3353\end{array}$ & $\begin{array}{l}23.04 \\
0.2865 \\
0.0112 \\
0.3406 \\
0.4150 \\
0.2178\end{array}$ \\
\hline $\begin{array}{l}\text { RV 'Else' } \\
\text { Effort Types } \\
1 \mathrm{~S} \& 2 \mathrm{~S}\end{array}$ & Hazard rate & $\begin{array}{c}900 \mathrm{~m} \\
(46)\end{array}$ & $\begin{array}{c}0.235 \\
(0.033)\end{array}$ & $\begin{array}{l}211.71 \\
(29.65)\end{array}$ & 14.01 & $\begin{array}{l}\text { Intercept of the scale parameter } \\
\text { Power parameter } \\
\text { Covariate CLUSTER SIZE }\end{array}$ & $\begin{array}{r}94.39 \\
1.978 \\
0.0241\end{array}$ & $\begin{array}{c}6.18 \\
4.293 \\
0.0204\end{array}$ \\
\hline $\begin{array}{l}\text { RV 'Toftevaag' } \\
\text { Effort Types } \\
1 \& 2\end{array}$ & Hazard rate & $\begin{array}{c}3600 \mathrm{~m} \\
(1321)\end{array}$ & $\begin{array}{c}0.187 \\
(0.006)\end{array}$ & $\begin{array}{l}672.86 \\
(20.49)\end{array}$ & 3.05 & $\begin{array}{l}\text { Intercept of the scale parameter } \\
\text { Power parameter } \\
\text { Level D of factor covariate OBS } \\
\text { Covariate LOGCLSIZE } \\
\text { Level } 0 \text { of factor covariate SEA } \\
\text { Level } 1 \text { of factor covariate SEA } \\
\text { Level FB of factor covariate CUE } \\
\text { Simple polynomial adjustment } \\
\text { term of order } 4\end{array}$ & $\begin{array}{c}144.8 \\
1.274 \\
-0.7801 \\
0.5315 \\
0.6368 \\
0.2202 \\
-0.8442 \\
-0.9578\end{array}$ & $\begin{array}{r}10.16 \\
0.5329 \\
0.1414 \\
0.1107 \\
0.2263 \\
0.1912 \\
0.1390 \\
0.0759\end{array}$ \\
\hline $\begin{array}{l}\text { RV 'Toftevaag' } \\
\text { Effort Types } \\
\text { 1S \& 2S }\end{array}$ & Hazard rate & $\begin{array}{c}1500 \mathrm{~m} \\
(301)\end{array}$ & $\begin{array}{c}0.148 \\
(0.010)\end{array}$ & $\begin{array}{l}221.94 \\
(14.85)\end{array}$ & 6.69 & $\begin{array}{l}\text { Intercept of the scale parameter } \\
\text { Power parameter } \\
\text { Level FB of factor covariate CUE } \\
\text { Covariate LOGCLSIZE } \\
\text { Level } 0 \text { of factor covariate SEA } \\
\text { Level } 1 \text { of factor covariate SEA } \\
\text { Covariate TIME }\end{array}$ & $\begin{array}{c}23.26 \\
1.275 \\
-0.8397 \\
0.5866 \\
2.1200 \\
0.5952 \\
0.0386\end{array}$ & $\begin{array}{c}3.74 \\
1.131 \\
0.2605 \\
0.2566 \\
0.5091 \\
0.2566 \\
0.0431\end{array}$ \\
\hline
\end{tabular}

hazard-rate key function with simple polynomial series expansion and one adjustment term. Four covariates were selected: position of the observer, sea state, cue and group size (Table 4, Fig. 2).

RV 'Toftevaag': Effort Types 1S and 2S. Perpendicular distance was truncated at $1500 \mathrm{~m}$, discarding $9.9 \%$ of the data, leaving 301 sightings for analysis. The best fitting model was a hazard-rate key function with no series expansion and adjustment terms. Four covariates were selected: sea state, cue, group size and time (Table 4, Fig. 2).

\section{Abundance models}

Visual comparison of plots of each covariate against the others revealed several moderate to high correlations. Correlated covariates were not generally used in the same model, but in a few cases the incorporation of 2 correlated covariates significantly improved the model fit.

The covariates retained in the 2 steps of the model for each dataset are shown in Table 5. The selection of covariates varied with area, but for the same area it was fairly similar from period to period. In none of the models were anthropogenic covariates selected. Figs. A1 to A6 (see Appendix, available as Supplementary Material at www.int-res.com/articles/suppl/ n004p309_app.pdf) show the relationships between both abundance of groups and group size with the environmental covariates, in the form of plots of the fitted functional forms for each covariate retained in the models.

\section{Estimated abundance and trends}

The point estimate of abundance for the whole area was 19428 (\% CV = 10.7 to $18.0 ; 95 \% \mathrm{CI}=15277$ to 22804 ) dolphins between 2000 and 2004, mainly concentrated in Southern Almería and the westernmost part of the Alborán Sea (Fig. 3c). Estimated average density was 1.01 dolphins $\mathrm{km}^{-2}$ (95\% $\mathrm{CI}=0.80$ to 1.19). In general, estimated density decreased from west to east for all datasets in this period (Fig. 3); these differences $(d)$ were significant ( $d_{\text {Alborán-Almería }}=2.449$, 


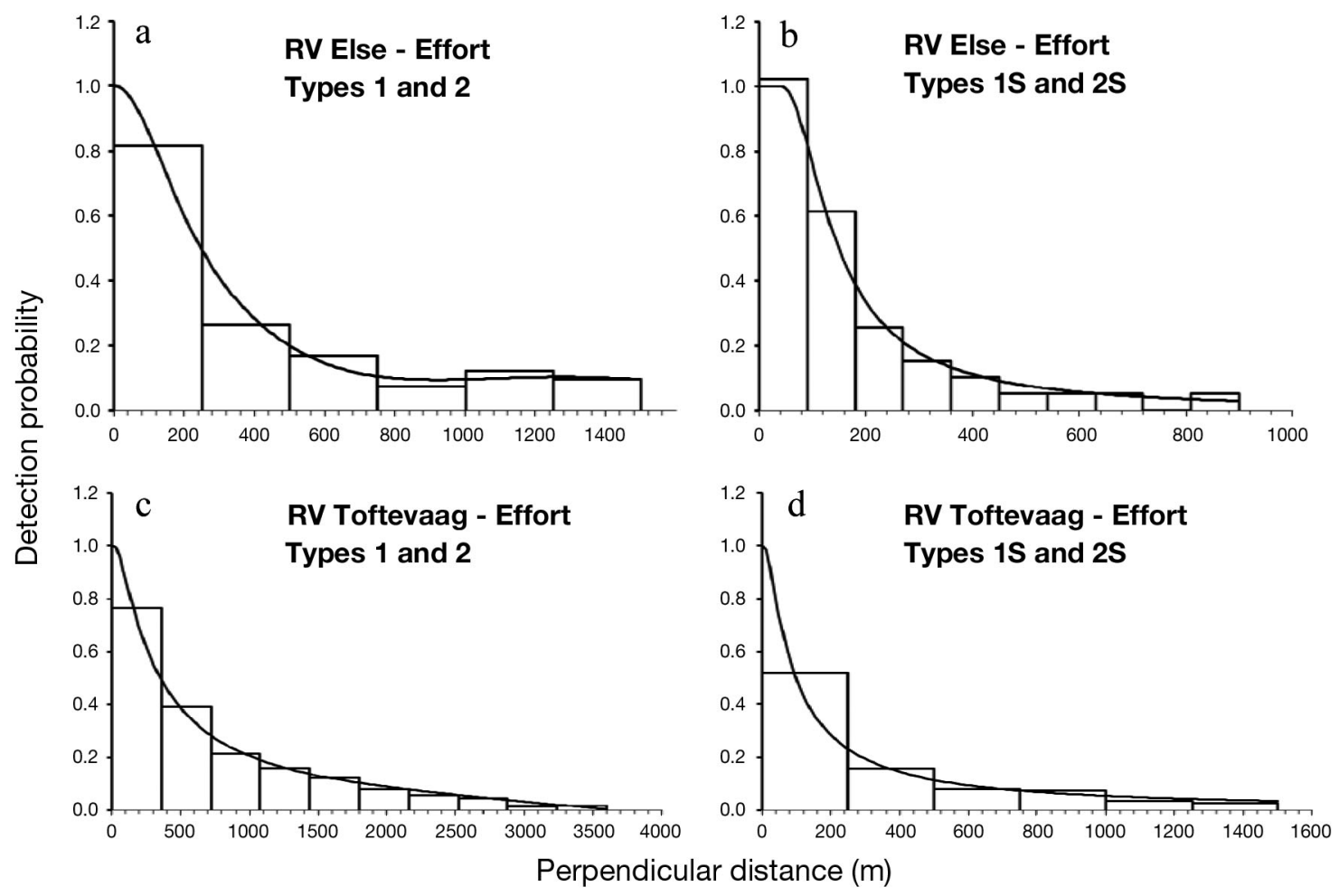

Fig. 2. Perpendicular distance distribution, pooled over all covariates (histograms), and fitted detection functions, conditional to the observed covariates (lines). (a) RV 'Else' with Effort Types 1 and 2, (b) RV 'Else' with Effort Types 1S and 2S, (c) RV 'Toftevaag' with Effort Types 1 and 2, (d) RV 'Toftevaag' with Effort types 1S and 2S. For a description of effort types, see 'Results; Detection function'

$\mathrm{p}<0.02 ; \mathrm{d}_{\text {Alborán-Vera }}=8.584, \mathrm{p}<0.001 ; \mathrm{d}_{\text {Almería-Vera }}=$ $5.152, \mathrm{p}<0.001)$.

For the area of Western Alborán, the estimated density was slightly higher in 2003-2004 than 2000-2002, but the differences are not significant. Therefore, we consider the abundance estimate for the whole period, from 2000 to 2004, as the best estimate: 13019 dolphins (1.72 dolphins $\mathrm{km}^{-2} ; \% \mathrm{CV}=11.8$ to $13.2 ; 95 \% \mathrm{CI}=$ 1.31 to 2.06) from the Western Alborán model, and 11721 dolphins (1.55 dolphins $\mathrm{km}^{-2}$; $95 \% \mathrm{CI}=1.21$ to 1.93) from the Alborán-Almería-Vera model.

There was no trend in the density estimate for the area of Southern Almería between 1992 and 2004, for any of the datasets explored. Therefore, we consider the density estimate for the whole period of $13 \mathrm{yr}$ as the best estimate: 4670 dolphins (1.10 dolphins $\mathrm{km}^{-2}$; \% CV $=8.6$ to $10.4 ; 95 \% \mathrm{CI}=0.87$ to 1.20 ). Fig. 4 shows the surface maps of estimated abundance for the area of Almería-Vera for the 4 periods: 1992-1995, 1996-1998, 2000-2004 and 1992-2004, where the distribution patterns are very similar. Fig. 5 shows the surface maps of estimated abundance for the area of Southern Almería for the periods: 1996-1998, 1999 and 2000-2004. There is a clear difference in the distribution pattern during 1999, with higher density towards deep waters (Fig. 5).
In the Gulf of Vera, a strong decline in density since 1992-1995 is evident. The estimated abundance for 1992 -1995 was 2893 dolphins (0.47 dolphins $\mathrm{km}^{-2}$; \% $\mathrm{CV}=13.5$ to $14.8 ; 95 \% \mathrm{CI}=0.35$ to 0.57 ), decreasing in 1996-1998 to an estimated abundance of 1223 animals $\left(0.20\right.$ dolphins $\mathrm{km}^{-2} ; \% \mathrm{CV}=31.8$ to 32.4 ; $95 \% \mathrm{CI}=0.10$ to 0.36 ), and to 1052 animals in 2000-2004 (0.17 dolphins $\mathrm{km}^{-2} ; \% \mathrm{CV}=23.0$ to 27.2; $95 \% \mathrm{CI}=0.11$ to 0.27 ). Differences were significant between the first period and the other $2\left(d_{9295-9698}=\right.$ $\left.2.490, \mathrm{p}<0.02 ; \mathrm{d}_{9295-0004}=3.858, \mathrm{p}<0.001\right)$. Fig. 6 shows the surface maps of estimated abundance for the area of Vera for the 2 periods. In both periods, depth was the only significant covariate in the model of abundance of groups, with a trend of preference for deeper waters in the second period, although group sizes were larger in shallower waters.

Density during winter was significantly lower than during summer in the Almería-Vera area $\left(\mathrm{d}_{\text {summer-winter }}\right.$ $=4.501, \mathrm{p}<0.001$ ), considering all years together. This difference is mainly due to a much smaller average group size during winter (Summer: mean group size $=$ $70.1, \mathrm{SE}=3.90 ;$ Winter: mean group size $=35.1, \mathrm{SE}=$ $6.63)$, while the encounter rate of groups was similar. There was also a shift in distribution, with higher density of groups towards deep waters (or lower latitude), 
Table 5. Model results for all datasets analysed. The 2 models are shown (abundance of groups ['groups'] and group size) for each row, giving the variables (' $:$ ' indicates an interaction between 2 variables) retained in the best model (estimated df in parentheses: 1 means a linear relationship), and the percentage of deviance explained by the model. See Table 1 for abbreviations. Numbers following all SST and chl variables indicate years over which the average was calculated, e.g. $0004=2000$ to 2004$)$. $g(y, v)$ : conditional probability of detection (always as a linear predictor). Variables are ordered from most to least significant according to their $\mathrm{p}$-value in the final model

\begin{tabular}{|c|c|c|c|}
\hline Subset & Model & Variables & $\begin{array}{l}\text { \% deviance } \\
\text { explained }\end{array}$ \\
\hline \multicolumn{4}{|l|}{ Winter } \\
\hline \multirow[t]{2}{*}{ Almería-Vera 1992-2004 } & Groups & tav9804:lat (4.5) & 4.4 \\
\hline & Group size & $\operatorname{dist1000}(1)+g(y, v)+$ cavi0004 (4.9) & 37.5 \\
\hline \multirow{2}{*}{ Almería 1992-2004 } & Groups & distcoast (5.2) & 2.3 \\
\hline & Group size & Cavi0004 (4.8) + dist1000 (5) $+g(y, v)$ & 43.9 \\
\hline \multicolumn{4}{|l|}{ Summer Alborán-Almería-Vera } \\
\hline \multirow[t]{2}{*}{ Alborán-Almería-Vera 2000-2002 } & Groups & tavv0002:lon:logdepth (17.6) & 10.5 \\
\hline & Group size & distcoast $(6.5)+\operatorname{lon}(7.9)+\mathrm{ci}(3.4)+g(y, v)$ & 23.3 \\
\hline \multirow[t]{2}{*}{ Alborán-Almería-Vera 2003-2004 } & Groups & tavv0304:lon (13.3) + logdepth:distcoast (19.1) + slope (3.1) & 25.4 \\
\hline & Group size & distcoast:ci $(5.3)+$ lon $(8.1)+g(y, v)$ & 31.9 \\
\hline \multirow{2}{*}{ Alborán-Almería-Vera 2000-2004 } & Groups & tavv0004:lo:logdepth (24.2) & 12.9 \\
\hline & Summer Almería-Vera & distcoast $(5.8)+$ lon $(3.6)+\operatorname{ci}(3.1)++g(y, v)$ & 18.7 \\
\hline \multirow[t]{2}{*}{ Almería-Vera 1992-1995 } & Groups & tds9804:dist1000 (3.4) & 3.2 \\
\hline & Group size & distcoast:cavv0004 (10.2) + cvdepth2 (6.8) + lat $(1)+g(y, v)$ & 28.8 \\
\hline \multirow[t]{2}{*}{ Almería-Vera 1996-1998 } & Groups & tavv9804:distcoast (9.7) & 9.1 \\
\hline & Group size & depth:lon $(8.4)+$ sddepth $(1)+g(y, v)$ & 24.0 \\
\hline \multirow[t]{2}{*}{ Almería-Vera 2000-2002 } & Groups & logdepth (3.6) + tavv0002:lon (3.8) & 9.5 \\
\hline & Group size & distcoast $(7.1)+$ cavv0002 $(1.6)+g(y, v)$ & 41.6 \\
\hline \multirow{2}{*}{ Almería-Vera 2003-2004 } & Groups & lat $(4.7)+$ lon $(4.1)+\operatorname{distcoast}(3.8)+$ slope $(2.2)$ & 20.0 \\
\hline & Group size & $\operatorname{dist1000}(5.3)+$ lon $(3)+g(y, v)$ & 51.3 \\
\hline \multirow[t]{2}{*}{ Almería-Vera 2000-2004 } & Groups & tavv9804:logdepth (8.7) & 9.7 \\
\hline & Group size & distcoast:cavv0004 (18.9) + lat $(1)+g(y, v)$ & 45.1 \\
\hline \multirow[t]{2}{*}{ Almería-Vera 1996-2004 } & Groups & tavv9804:logdepth (10.4) & 6.8 \\
\hline & Group size & distcoast :cavv0004 (10.2) + cvdepth2 (6.8) + lat $(1)+g(y, v)$ & ) 28.8 \\
\hline \multirow{2}{*}{ Almería-Vera 1992-2004 } & Groups & tav9804 (5.6) & 3.2 \\
\hline & Group size & cavv0004 :logdepth (10.1) & 18.9 \\
\hline \multicolumn{4}{|l|}{ Summer Western Alborán } \\
\hline \multirow[t]{2}{*}{ Western Alborán 2000-2002 } & Groups & cavv0002:depth (3.2) & 3.8 \\
\hline & Group size & $\operatorname{ersl1}(1)+\operatorname{ersl2}(4.3)+g(y, v)$ & 11.2 \\
\hline \multirow[t]{2}{*}{ Western Alborán 2003-2004 } & Groups & cavv0004 (5.5) + dist200 (7.4) + ci (3.7) & 15.8 \\
\hline & Group size & distcoast $(3.3)+\mathrm{ci}(1)+g(y, v)$ & 17.2 \\
\hline \multirow[t]{2}{*}{ Western Alborán 2000-2004 } & Groups & cavv0004:logdepth (9.1) & 4.9 \\
\hline & Group size & dist200 (1) + ersl1 $(1)+g(y, v)$ & 8.8 \\
\hline \multicolumn{4}{|l|}{ Summer Southern Almería } \\
\hline \multirow[t]{2}{*}{ Southern Almería 1996-1998 } & Groups & distcoast $(4.5)+$ lon (3.4) & 6.2 \\
\hline & Group size & depth $(4.5)+\mathrm{ci}(1)+g(y, v)$ & 17.1 \\
\hline \multirow[t]{2}{*}{ Southern Almería 1999} & Groups & depth $(4.4)+$ cavv0004 (2.7) & 14.1 \\
\hline & Group size & cavv0004 (7.6) $+g(y, v)$ & 49.1 \\
\hline \multirow[t]{2}{*}{ Southern Almería 2000-2004 } & Groups & logdepth (3.7) & 4.2 \\
\hline & Group size & logdistcoast $(7.6)+\mathrm{ci}(1)+g(y, v)$ & 30.5 \\
\hline \multicolumn{4}{|l|}{ Summer Gulf of Vera } \\
\hline Gulf of Vera 1992-1995 & Groups & depth (2.1) & 3.0 \\
\hline & Group size & sddepth $(5.4)+$ logdepth:tav0004 (8.0) $+g(y, v)$ & 28.1 \\
\hline Gulf of Vera 1996-2004 & Groups & depth (1) & 2.1 \\
\hline & Group size & distcoast $(8.1)+$ cvdepth $(3.1)+q(y, v)+$ lat $(1.7)$ & 91.1 \\
\hline
\end{tabular}

but still with higher density in Southern Almería compared to the Gulf of Vera. Despite the smaller group sizes in this period, larger groups still occurred in shallower waters, where the chlorophyll concentration is higher. It was not possible to estimate abundance for winter in the Gulf of Vera due to the small sample size. Fig. 7 shows the surface map of estimated winter abundance for the area of Almería-Vera for the whole period 1992 to 2004 .

\section{Habitat use}

General patterns

Figs. A1 to A6 (Appendix 1) show the functional forms of the fitted relationships both between abundance of groups and explanatory covariates and between group size and explanatory covariates.

Abundance of groups. The most important covariate for the main datasets (Alborán-Vera and Almería- 


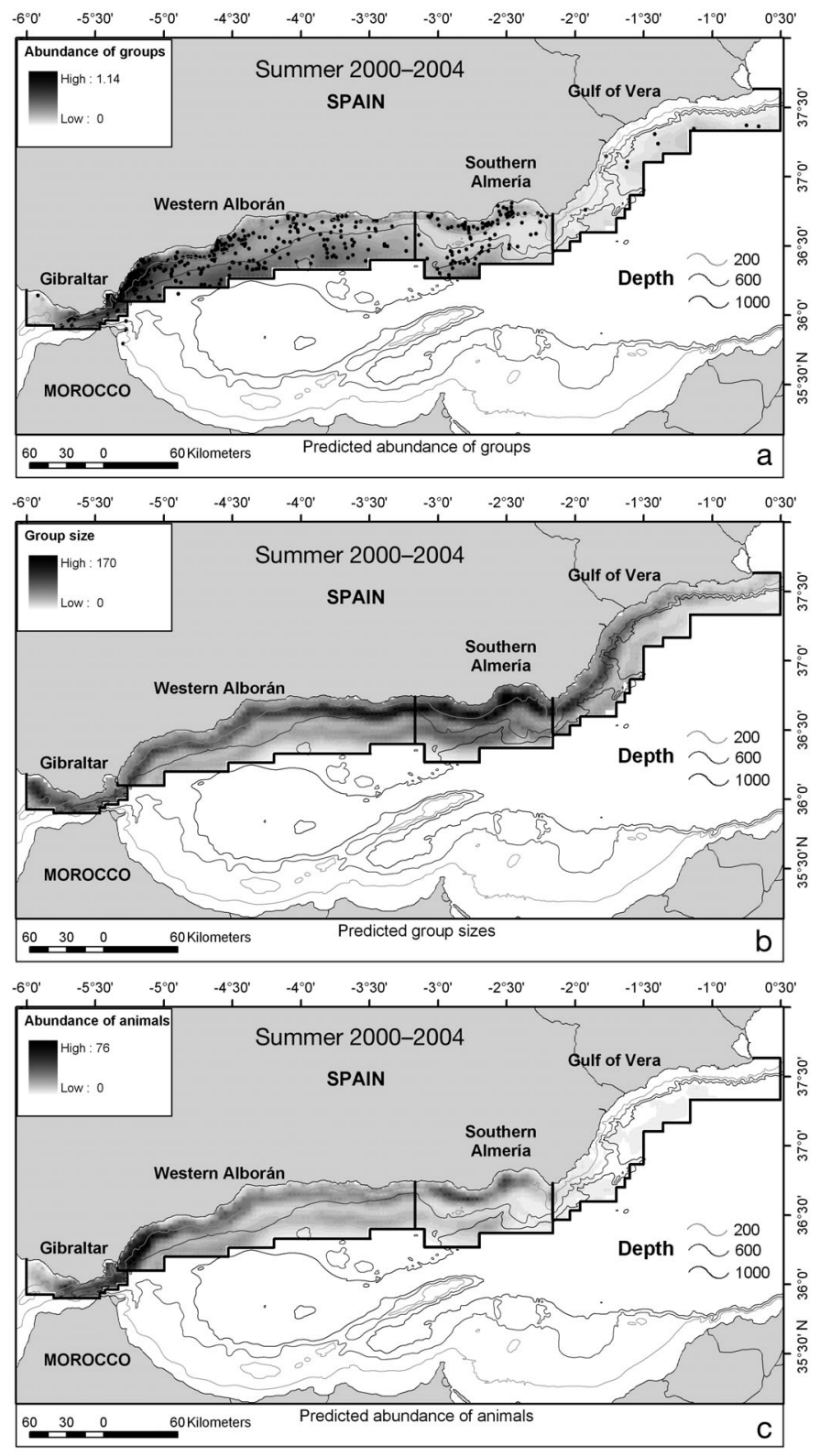

Fig. 3. Delphinus delphis. Surface maps of (a) predicted abundance of groups, (b) predicted group sizes and (c) predicted abundance of animals for the whole study area between 2000 and 2004.

Black dots represent groups encountered during this period

Vera), during both summer and winter, was sea surface temperature (SST), with a clear preference for cooler waters (Table 5), around 18 to $20^{\circ} \mathrm{C}$. The other important covariate in these datasets was from the depth group. Very often these covariates were selected as an interaction term between both. The general trend was for larger abundance of groups towards the west and for bimodality with depth, with a peak around the shelf break (150 to $200 \mathrm{~m}$ depth) and another in deep waters around $1000 \mathrm{~m}$ depth

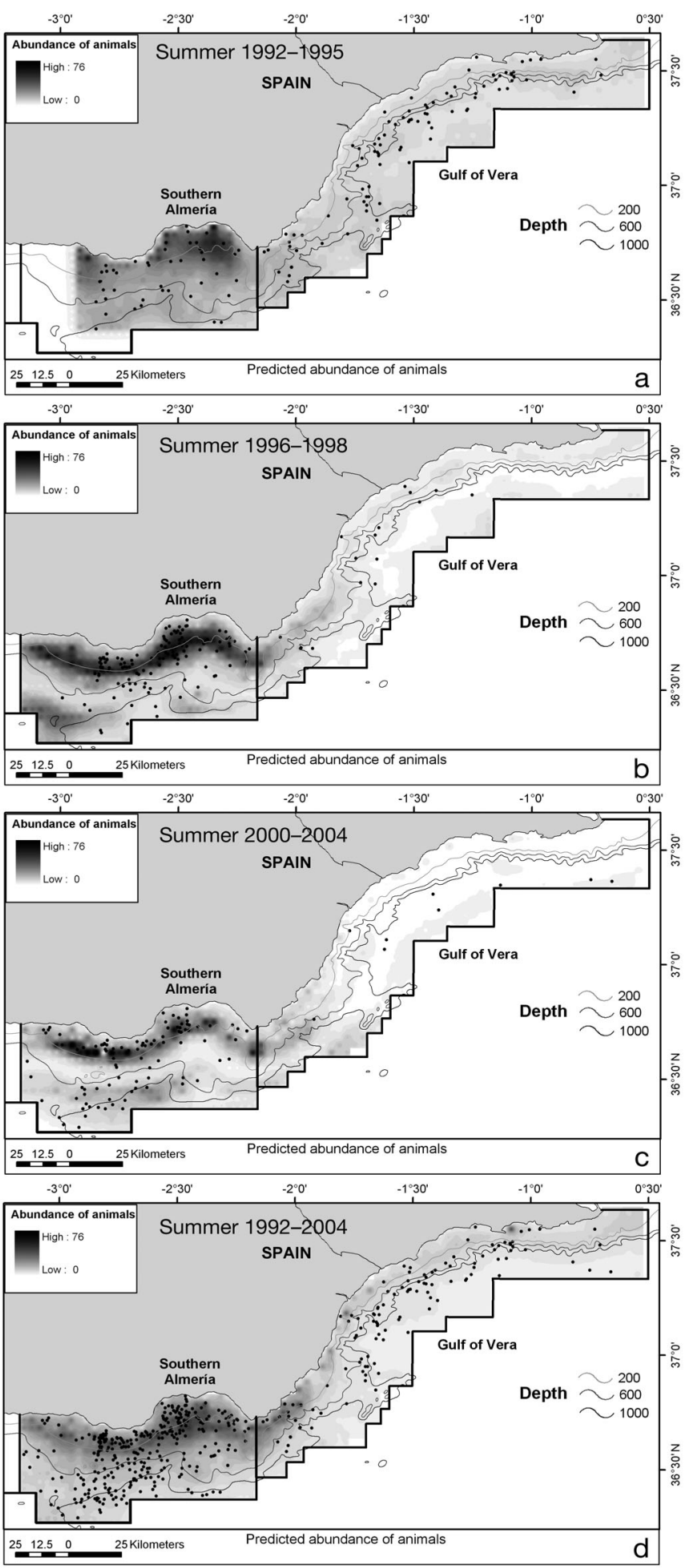

Fig. 4. Delphinus delphis. Surface maps of predicted abundance of animals for the area of Almería-Vera (a) between 1992 and 1995, (b) between 1996 and 1998, (c) between 2000 and 2004, and (d) whole period, between 1992 and 2004. The white area in the lower left corner of the 1992-1995 map represents an unsurveyed area in that period. Black dots represent encountered groups for each period. The scales for all maps are the same as in Fig. 3c, for comparison 


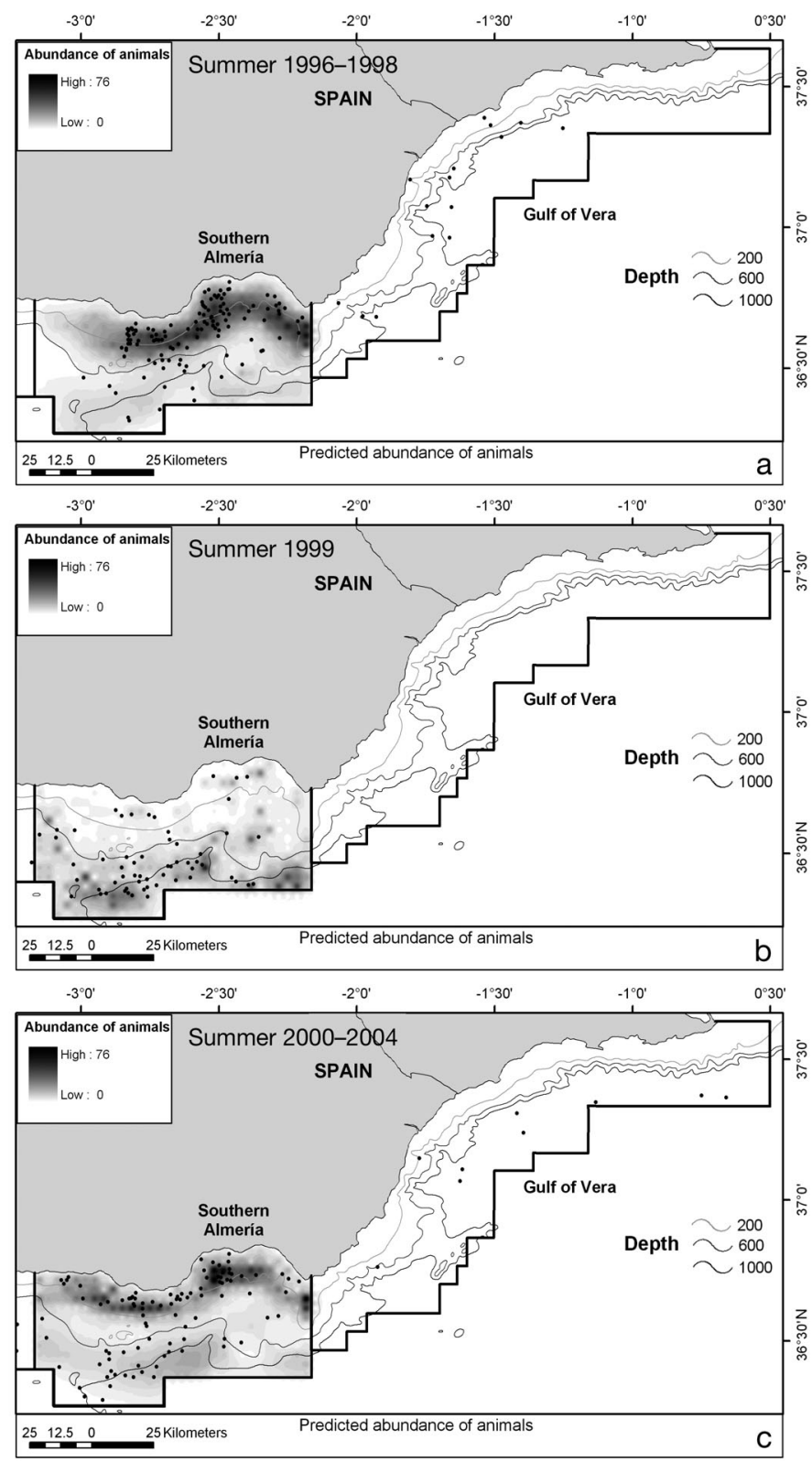

Fig. 5. Delphinus delphis. Surface maps of predicted abundance of animals for the area off Southern Almería (a) between 1996 and 1998, (b) 1999, and (c) between 2000 and 2004. Black dots represent encountered groups for each period. The scales of all 3 maps are the same as in Figs. 3c \& 4, for comparison

(Fig. 3a). The same pattern was observed in winter in Almería-Vera.

In the models of abundance of groups for the subsets of data, SST was not selected. However, average chlorophyll concentration was selected in the 3 models of the Western Alborán dataset, with a strong increase in abundance towards areas of higher chlorophyll concentrations. The most common covariate selected in the model of abundance of groups for all 3 small areas,

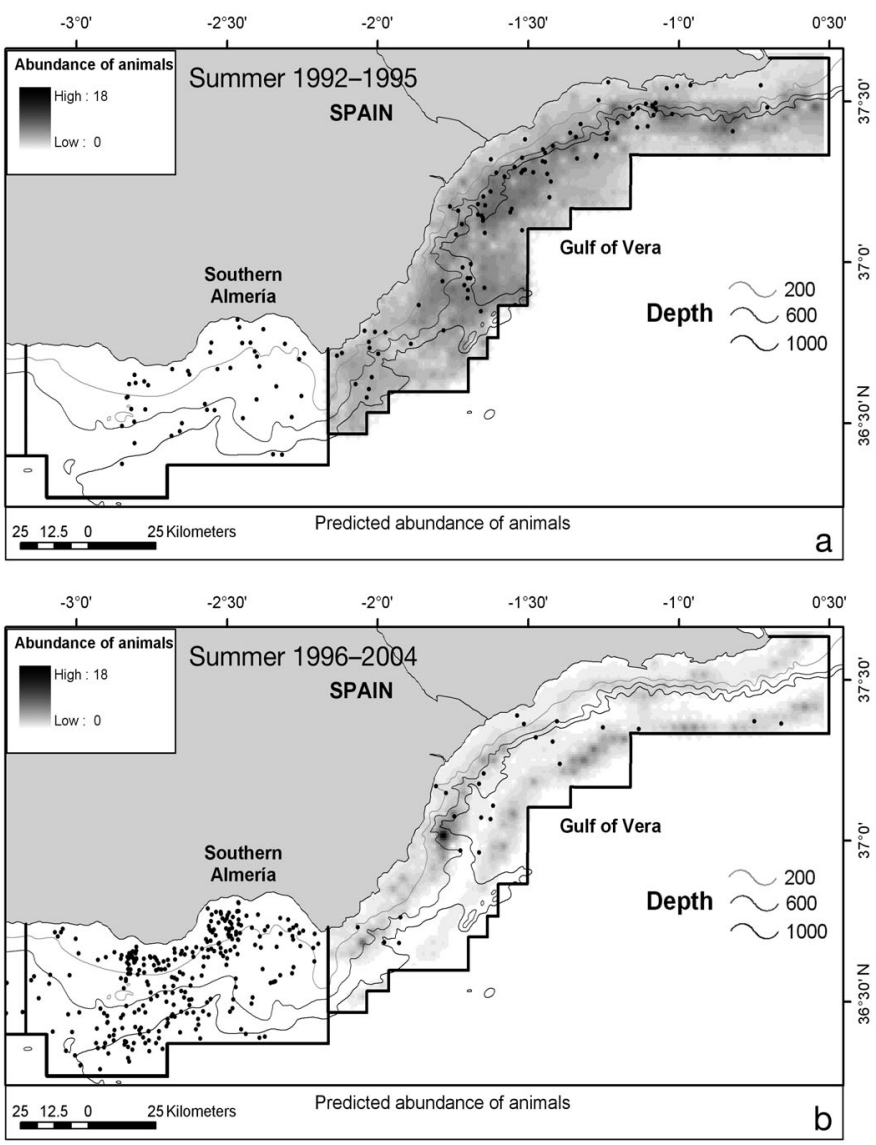

Fig. 6. Delphinus delphis. Surface maps of predicted abundance of animals for the area of the Gulf of Vera (a) between 1992 and 1995, and (b) between 1996 and 2004. The scales of the 2 maps are the same, for comparison, but different from the previous figures as the density is much lower

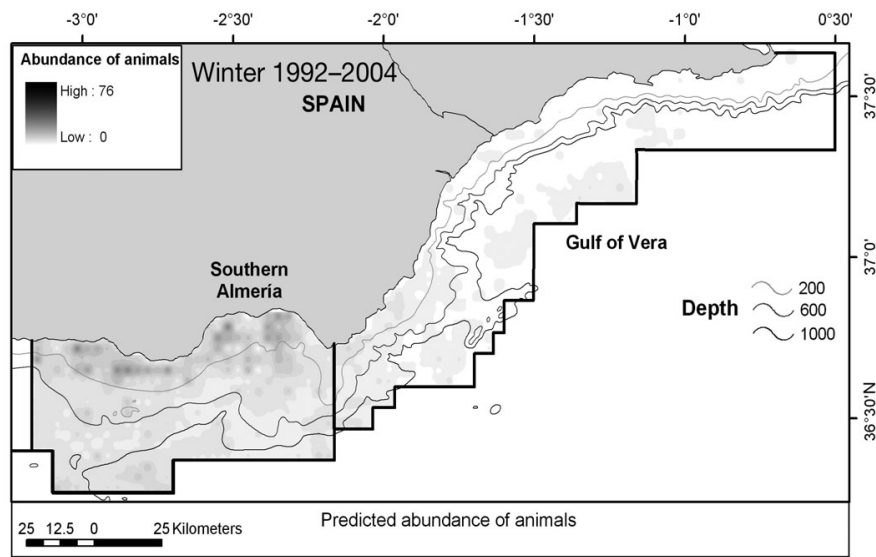

Fig. 7. Delphinus delphis. Surface map of predicted abundance of animals for winter in the Almería-Vera area for the whole period, 1992 to 2004. The scale of the map is the same as for the summer season (Fig. 4), for comparison 
including winter, was one from the depth group. Again the trend was for bimodality, except in the Gulf of Vera and in Southern Almería in 1999, where only 1 peak of higher density was predicted in deep waters in both cases.

Group sizes. When modelling the group sizes, the most common covariate selected was one from the depth group, usually distance from coast (Table 5). In all datasets, there was invariably a clear trend for larger group sizes at the edge of the continental shelf, and especially in Southern Almería, as described in Cañadas et al. (2005); there was also sometimes a second much smaller peak around depths of $1000 \mathrm{~m}$ (Fig. 3b). The reason why distance from coast may sometimes be more important than depth is dealt with in 'Discussion; Investigation of habitat preferences'.

Abundance of animals. In general, the bimodal pattern was also reflected in the predicted distribution of abundance of animals, with higher densities around the shelf edge and a second peak in deep waters (Figs. 3c, 4 \& 5a,c). The exceptions were Southern Almería in 1999 (Fig. 5b) and the Gulf of Vera (Fig. 6), where there was a higher abundance of animals in deep waters. The tendency for there to be higher abundance towards the west, and a second peak in Southern Almería, was clearly reflected in most cases. There was very low density predicted in the Gulf of Vera, decreasing northwards from Almería (Fig. 4).
Influence of biological factors

Figs. A7 to A9 (Appendix 1) show the functional forms of the fitted relationships both between density of groups and explanatory covariates and between group size and explanatory covariates, for the three biological factors investigated: Fig. A7 for the presence of calves, Fig. A8 for single and mixed species groups and Fig. A9 for behaviour.

Presence of calves. In those groups in which the presence or absence of calves could be determined, calves were present in $41 \%$. The proportion of groups with calves was significantly larger during the summer months than during the winter months $\left(\chi^{2}=10.4, \mathrm{df}=1\right.$, $\mathrm{p}=0.0013$ ), but no differences were observed among areas in any season. There were no differences in the proportion of groups with calves among years.

The covariates retained in the 2 steps of the model for each dataset are shown in Table 6. Groups with calves showed preference for more coastal waters, while none of the explanatory covariates were significant in the models of group size. Groups without calves showed a preference for deeper waters, with larger group sizes in areas around the shelf edge with moderate SST, found in the central part of the study area (mainly in Southern Almería and Málaga). As a result, the abundance of animals in groups with calves was highest around the shelf edge in the western half of the

Table 6. Model results for all the datasets analysed. The 2 models are shown (abundance of groups and group size), giving the variables (' $\because$ ' indicates an interaction between 2 variables) retained in the best model (estimated df in parentheses: 1 means a linear relationship), and the percentage of deviance explained by the model. For abbreviations of variables, see Fig. 5. Variables are ordered from more to less significant according to their $\mathrm{p}$-value in the final model

\begin{tabular}{|c|c|c|c|}
\hline Subset & Model & Variables & $\begin{array}{c}\% \text { deviance } \\
\text { explained }\end{array}$ \\
\hline \multicolumn{4}{|l|}{ Calves } \\
\hline \multirow[t]{2}{*}{ With calves } & Groups & depth:lon (4.8) & 4.5 \\
\hline & Group size & distcoast $(5.5)+$ tavv9804 $(3.3)+g(y, v)$ & 18.8 \\
\hline \multirow[t]{2}{*}{ No calves } & Groups & tavv9804 (1.7) + logdepth (4.3) + ci (3.3) & 7.6 \\
\hline & Group size & - & \\
\hline \multicolumn{4}{|l|}{ Groups (with striped dolphins) } \\
\hline \multirow[t]{2}{*}{ Single groups } & Groups & tavv9804:logdepth (11.6) & 7.4 \\
\hline & Group size & distcoast $(7.6)+$ lon $(2.1)+\mathrm{ci}(3.6)+g(y, \mathrm{v})$ & 17.2 \\
\hline \multirow{2}{*}{ Mixed groups } & Groups & logdepth:lat (5.1) & 9.1 \\
\hline & Group size & depth $(2.2)+\mathrm{ci}(2.3)+g(y, v)$ & 25.6 \\
\hline \multirow{3}{*}{$\begin{array}{l}\text { Proportion of common dolphins in mixed groups } \\
\text { Behaviour } \\
\text { Travelling }\end{array}$} & Proportion & depth $(2.7)$ & 29.4 \\
\hline & Groups & tavv9804:logdepth (11.3) & 7.2 \\
\hline & Group size & distcoast $(5.5)+$ tavv9804 $(3.3)+g(y, v)$ & 18.8 \\
\hline \multirow[t]{2}{*}{ Feeding } & Groups & tavv9804:logdepth (5.0) & 9.4 \\
\hline & Group size & - & \\
\hline \multirow[t]{2}{*}{ Socialising } & Groups & tavv9804:dist200 (5.6) & 5.2 \\
\hline & Group size & lon $(4.9)+\operatorname{dist} 200(1)+g(y, v)$ & 28.1 \\
\hline \multirow[t]{2}{*}{ Socialising single groups } & Groups & lon (5.3) + depth (1) & 5.2 \\
\hline & Group size & lon $(3.0)+\operatorname{dist200}(1)+g(y, v)$ & 32.5 \\
\hline \multirow[t]{2}{*}{ Socialising mixed groups } & Groups & tavv9804:logdepth (10.8) & 13.0 \\
\hline & Group size & dist200 (1) $+g(y, v)$ & 21.2 \\
\hline
\end{tabular}



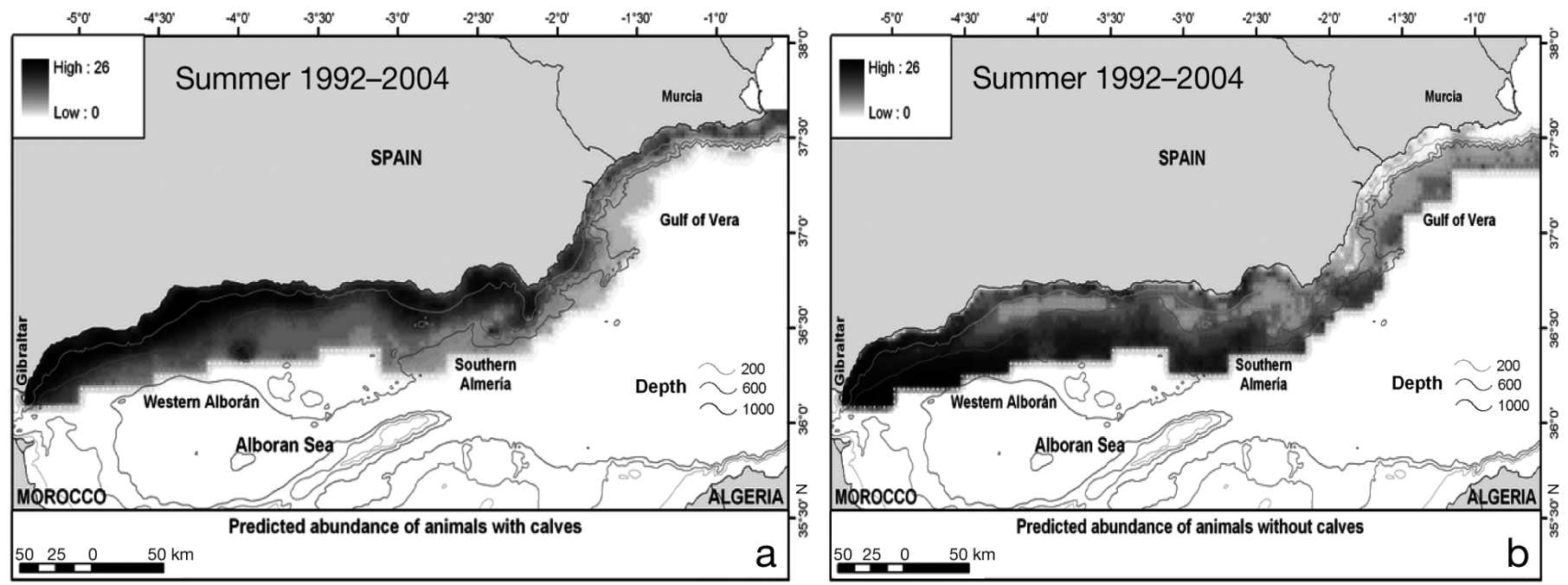

Fig. 8. Delphinus delphis. Surface maps of predicted abundance of animals for groups (a) with calves and (b) without calves

Alborán Sea, with a second smaller concentration off Southern Almería (Fig. 8a). The abundance of animals in groups without calves was highest in deep waters and towards the west (Fig. 8b).

Single and mixed species groups. Common dolphins were found in mixed species groups with striped dolphins in $22 \%$ of the sightings. There were no differences in the proportion of mixed groups encountered by month $\left(\chi^{2}=12.4, \mathrm{df}=6\right)$ or between Gibraltar, Western Alborán, Southern Almería and Vera $\left(\chi^{2}=1.4\right.$, df $=$ $3)$. The covariates retained in the 2 steps of the model for each dataset are shown in Table 6.There is a higher density of single species groups in the western part of the study area, and some bimodality in the rest of the area, with groups being more abundant in coastal waters. In contrast, mixed groups showed a marked tendency for higher density towards the deepest waters throughout the study area. Larger group sizes were predicted around the shelf edge in both cases, but predicted in greater concentration off Southern Almería and with a smaller second peak in deeper waters, in the case of single species groups.

In the resulting surface maps of abundance of animals (Fig. 9), single species groups followed the general pattern of higher densities around the shelf edge off Southern Almería, though concentrated in the western part of the area, while there were higher densities of animals in mixed species groups in the deep waters off Southern Almería, and in the whole western part of the study area. In the westernmost section, however, higher density also occurred around the shelf edge. In the mixed species groups, there was a strong contrast
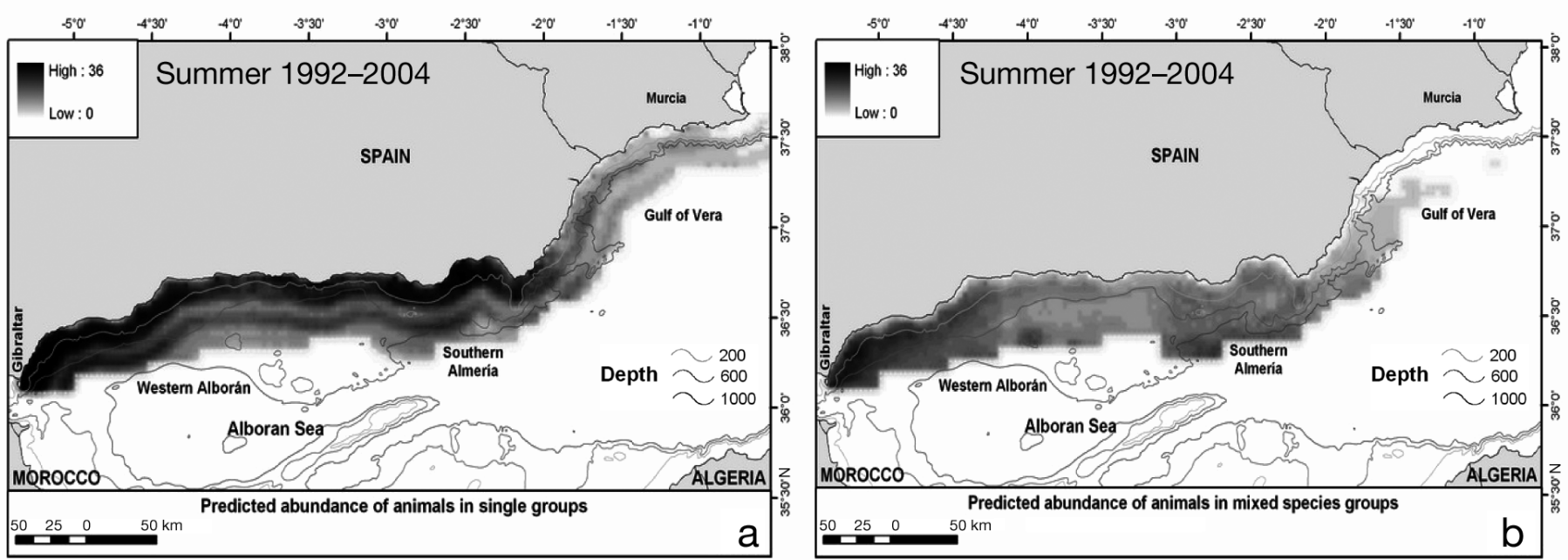

Fig. 9. Delphinus delphis and Stenella coeruleoalba. Surface maps of predicted abundance of animals for (a) single species groups (D. delphis) and (b) mixed species groups with striped dolphins (D. delphis and S. coeruleoalba) 

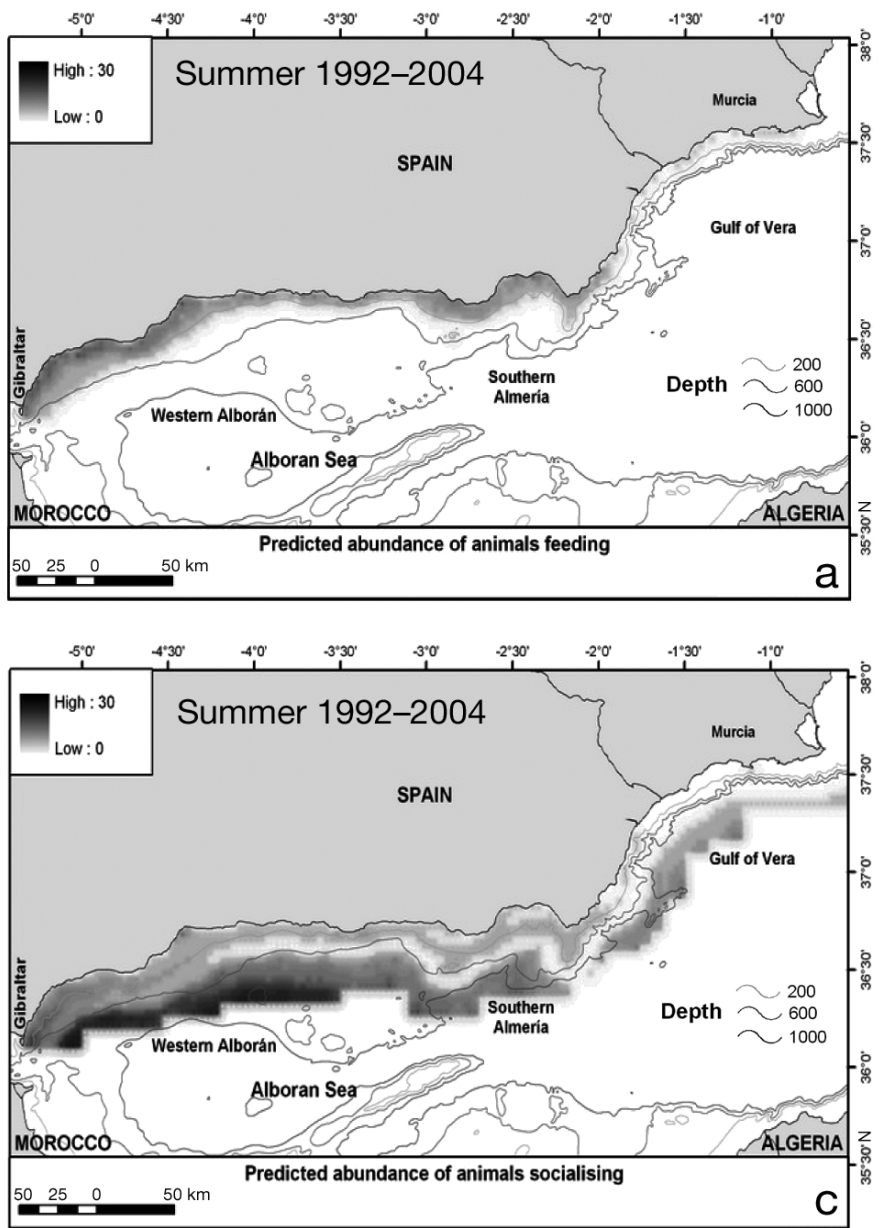

between the patterns of density of groups and of group sizes. The proportion of common dolphins in the mixed species groups decreased towards deep waters.

Behaviour. In $66 \%$ of the groups encountered, the animals were travelling, in $9.2 \%$ they were feeding, in $9.8 \%$ they were socialising, in $15 \%$ they were classified as milling, and in $1 \%$ they were resting. This last category was excluded from the spatial analysis due to its small sample size. 'Milling' was also excluded because it is a very loose category which is very difficult to interpret. There were significant differences in the proportion of the different behavioural categories amongst months $\left(\chi^{2}=51.1, \mathrm{df}=18, \mathrm{p}<0.0001\right)$. These differences were due mainly to the absence of observations of socialising behaviour during the winter months.

The covariates retained in the 2 steps of the model for each dataset are shown in Table 6. For groups feeding, the abundance of groups was multiplied by the mean group size of that dataset to give a surface map of animal abundance, because none of the covariates were significant in the model of group sizes. The largest abundance occurred in the areas closest to the coast (Fig. 10a). Animals travelling followed the general pattern of higher densities towards the west and

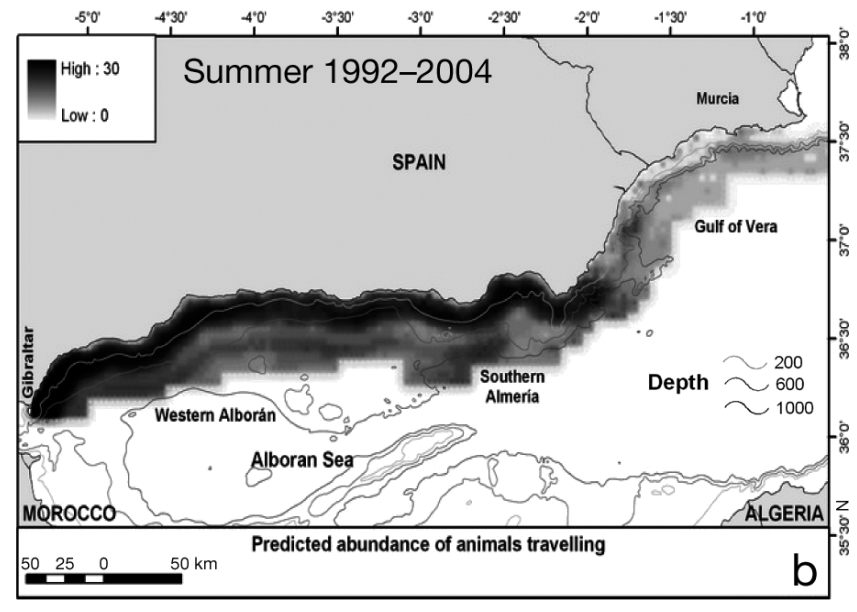

Fig. 10. Delphinus delphis. Surface maps of predicted abundance of animals for (a) groups feeding, (b) groups travelling, and (c) groups socialising

around the shelf edge, mainly due to larger group sizes in these shallow waters, with a second smaller peak in deep waters, in this case mainly due to larger abundance of small groups (Fig. 10b). There was a strong contrast between the patterns of abundance of groups and of group size in socialising groups, yielding a strong bimodal pattern (Fig. 10c) with more, but smaller, groups in deep waters, and fewer, but larger, groups in shallow waters around the shelf edge.

\section{DISCUSSION}

\section{Methodological considerations}

Modelling distribution

The fitted models are not complex in that they do not include many explanatory covariates (usually 3 or less and a maximum of 5 terms). Therefore, we do not believe the models are overfitted. Nevertheless, they do sometimes contain combinations of covariates that do not have clear biological interpretations. This may have occurred less if we had limited our 
choice of covariates; however, our aim was to account for as much variation as possible in the data.

The models of group density explained a low percentage of deviance; there may be several reasons for this. First, the models may not be a good description of the data. However, comparison of the surface maps with the observed distribution of sightings, and the large similarities among datasets, suggest that the general distribution pattern of common dolphins in the area has been adequately captured by the models.

Another important reason why such a low percentage of deviance is explained is the complexity of the species' ecology. Distribution and abundance are certainly influenced by environmental features for which we had no data, in particular the distribution and abundance of their prey, information on which is difficult to quantify and/or unavailable. The covariates used are proxies to help describe patterns in distribution rather than the reasons for it (i.e. these are 'predictive' (descriptive) models, not 'explanatory' (processbased) models; MacNally 2000).

A third factor that could reduce the variability explained is the spatial scale of the study area, in relation to the habitat use of the species. If density varies little over the area modelled, spatial covariates will not be able to explain much variability. In the present study the deviance explained in the larger datasets (Alborán-Vera) is higher than in the smaller datasets (Table 6).

The estimated density for a sub-area extracted from a larger dataset and the density estimated by modelling the smaller datasets separately were very similar, inferring that the relationship between density and the environmental covariates is similar at both scales. However, the CV and $95 \%$ CI increased as the area modelled became smaller, which was likely (1) because density varied less over the smaller areas, and (2) a consequence of smaller sample size. For example, for the area of Southern Almería between 2000 and 2004, the estimated density when modelling this dataset on its own was 1.02 ( \% CV $=30.8$ to 31.3 ); when extracted from the model of the larger Almería-Vera dataset, it was 0.85 ( $\% \mathrm{CV}=22.3$ to 23.1 ), and when extracted from the model of the largest Alborán-Vera dataset, the estimated density was 0.97 (\% CV $=14.9$ to 16.1 ). In general, however, caution should be exercised when applying a model fitted to a larger area to the data for a smaller area, and vice versa, because the relationship between density and the covariates may not be the same for the larger and the smaller areas.

Bias in abundance estimation

The tests we performed indicate that responsive movement before detection did not appear to be a problem in the present study; however, strong attraction of common dolphins to the observation platform has been found in other studies (e.g. Cañadas et al. 2004). We conclude that the small size, relatively slow speed and quietness of the research vessel, combined with the typically large detection distance of common dolphin groups, meant that groups were detected before any reaction occurred.

It was not possible to estimate the probability of detection on the transect line, $g(0)$, because the double platform method was not implemented in this study. Nevertheless, we believe that due to the large group sizes and the relatively long time available for detecting animals (as influenced by survey speed, distance searched ahead of the vessel, sighting conditions and relatively short dive times (personal observations similar to Ferretti's (1999) mean $=23.3 \mathrm{~s}, \mathrm{SD}=22.6$, mode $=11$ ) in this survey, $g(0)$ was very likely to be close to 1. In the North Atlantic Sightings Survey 1995 (NASS95), the smaller group sizes, faster survey speed and worse conditions gave an estimated $g(0)=0.8$ (Cañadas et al. 2004). The potential negative bias assuming $g(0)=1$ is therefore likely to be small. Double platform data are being collected from 2005, so we will be able to test this assertion in future.

\section{Rounding angles and distances}

Distances were always estimated by the naked eye and rounded to convenient values; the data were smeared to minimise problems associated with this. We do not believe that distances were consistently under- or overestimated, but if they were, then this would lead to bias in estimates of density - positive bias if distances were underestimated, and negative bias if they were overestimated. No changes in methods to collect distance data were made over the course of the study, so trends in abundance should remain unaffected.

In addition to the above considerations of bias, determining angles and distances by eye leads to variability which is unaccounted for in our analysis. This means that the CVs of estimated abundance are underestimated, particularly for the earlier years.

\section{Variations in abundance and habitat preferences}

\section{Regional variations}

There is a clear density gradient of common dolphins from west to east (i.e. from greater to lesser influence of the Atlantic inflow through the Strait of Gibraltar), following the positive gradient in SST, especially 
around the shelf edge, and dropping steeply in the Gulf of Vera (Fig. 3c), where the influence is predominantly Mediterranean (i.e. warmer SST, lower productivity, etc.).

When modelling the data subsets (Western Alborán, Southern Almería and Gulf of Vera), SSTwas not selected, probably due to a smaller contrast in mean SST within such small areas. In Western Alborán, the chlorophyll concentration shows strong contrasts due to the presence of the Western Alborán gyre, an anticyclonic current of cooler and more productive waters coming from the Atlantic (Gascard \& Richez 1985, Parrilla \& Kinder 1987), which can explain the strong increase in density towards areas of higher chlorophyll concentrations in the 3 models of the Western Alborán dataset (Table 5). In the other small areas (Southern Almería and Gulf of Vera), the contrast in chlorophyll concentration within the area is small.

Group sizes were in general larger around the shelf edge, and especially off Southern Almería (Fig. 3b), despite the higher productivity in Western Alborán. This is probably due to different distribution patterns of the prey. It is believed that the formation of large groups benefits predation on large patches of prey, where prey is abundant enough for each member of the group to profit (Neumann 2001b). If the prey is distributed over many small patches, it is probably more efficient for the dolphins to split into smaller groups. Unfortunately, no information is available on the level of 'patchiness' of possible prey in Western Alborán and Southern Almería, so that we were unable to test whether this could be a main reason for the presence of a large number of small groups in Western Alborán, and the smaller number of larger groups off Southern Almería. The scattering layer, selected in the models of group size for Western Alborán, is an indication of high density of biomass (either zooplankton or small fish), which is especially marked in Western Alborán due to the very high productivity of the area. It is not surprising then, that common dolphins concentrate in this area.

There is no information on the diet of common dolphins in the study area, except for direct observations of feeding behaviour by the research team. During these observations, when the target prey species could be identified, it was either European sardine Sardina pilchardus, round sardinella Sardinella aurita or needle fish Belone belone. According to other studies around the world, this species appears to be an opportunistic feeder (Klinowska 1991, Young \& Cockcroft 1994, Gannier 1995), targeting mainly small, neritic, epipelagic fish, especially of the Clupeidae family and some of the Gadidae family, as well as a small amount of cephalopods (Young \& Cockcroft 1994, Kenney et al. 1995, Cordeiro 1996, Santos et al. 1996). Most of the small epipelagic fish, but especially the sardines, have distribution patterns strongly linked to high productivity areas, as they feed mainly on zooplankton (Lotina 1985a). In the study area, the inflow of Atlantic water and its associated currents create important upwellings of high productivity (with higher chlorophyll concentrations and cooler SST), especially along the coastal waters of the Western Alborán area and, to a lesser extent, in Southern Almería (Rubín et al. 1992). Furthermore, there is an area of very high productivity off Southern Almería, north of the sea mount 'Seco de los Olivos', which is apparently not caused by the Atlantic inflow but by an in situ effect due to bottom topography (Rubín et al. 1992, Rodríguez et al. 1994). The types of fish mentioned above tend to aggregate in these high productivity areas (Gil 1992). The covariates selected in the models, and how they relate to dolphin density, seem to be in accordance with this.

In the Gulf of Vera both the density of groups and the predicted group sizes were much smaller than in the neighbouring area of Southern Almería. The influence of Atlantic water inflow is much smaller here (Díaz del Rio 1991), as most of it runs along the so-called Almería-Oran front towards the Algerian coast of North Africa (Millot 1985, Tintoré et al. 1988), leaving the Gulf of Vera with most typical 'Mediterranean' oceanographic characteristics, much poorer than the Alborán Sea (Díaz del Rio 1991). On the other hand, the continental shelf in this area is extremely narrow. The density of European sardines in this area is lower than in the Alborán Sea (Abad et al. 1987, Gil 1992), probably mostly due to the reasons mentioned above. Therefore, it is possible that common dolphins in this area rely on different prey species, and hence show a different distribution pattern. When the density of common dolphins declined in this area, their distribution pattern also moved towards even deeper waters (Fig. 6). Unfortunately, there are no data available on distribution and density in the areas outside the study area, except for the known extremely low density of the species north of the Gulf of Vera (Universidad de Barcelona 2002, Universidad de Valencia 2002). In the northeastern Atlantic the highest densities of common dolphins during summer occur in deep waters (400 to 2000 m) (Cañadas et al. 2004, in press, Northridge et al. 2004, Brereton et al. 2005).

\section{Seasonal variations}

A seasonal change in distribution and density was observed, characterised by lower estimated density in winter due to the groups being smaller, and a shift in high density of groups towards deeper waters in winter compared to summer. A similar pattern was observed in New Zealand by Neumann (2001a), where common 
dolphins move offshore in autumn and winter and inshore in spring and summer. Neumann (2001) links this seasonal movement to changes in SST, suggesting that common dolphins prefer the warmer waters offshore during winter.

On the other hand, the opposite situation has been described for this species in the northeastern Atlantic, where common dolphins are more abundant in offshore waters $(>400 \mathrm{~m})$ than over the continental shelf during summer (Cañadas et al. in press), but move towards shallower waters of the continental shelf during winter (Pollock et al. 1997, Ó Cadhla et al. 2003, Northridge et al. 2004, Brereton et al. 2005). It has been suggested that this shift follows the migration movements of anchovies (Borja et al. 1998, Allain et al. 2001). In the Alborán Sea, sardines move towards deeper waters to hibernate when the SST drops in autumn, not returning to the epipelagic area until the end of spring or beginning of summer to feed (Lotina 1985b). In winter, common dolphins may adopt a different strategy for feeding, possibly on different prey species, by spreading out towards deeper waters in smaller groups. The same change in pattern occurred during summer 1999, when a drop in SST was detected on some days. This could suggest that common dolphins reacted in the same way as they do in winter, possibly related to a similar change in the prey availability, yielding a lower density of animals in the study area (Cañadas et al. 2002).

\section{Inter-annual variations}

No trend in abundance over time in the Alborán Sea as a whole has been detected in Southern Almería since 1992 or in Western Alborán since 2000 (Table 5), suggesting that the northern Alborán Sea population of common dolphins is stable in this area, at least during the time frame of the present study.

On the other hand, the sharp drop in density of common dolphins in the Gulf of Vera after 1996, to less than half of that between 1992 and 1995 is a concern, and may represent a significant adverse change in habitat quality. There is no information on what might have happened to these animals. The most parsimonious explanation is that they have moved to deeper water, to the Alborán Sea or to the African coast.

In 1999 there was a clear change in the distribution pattern of groups in Southern Almería. This change towards deep waters (Fig. 5b) was described and discussed in Cañadas et al. (2002). That specific year, a drop in SST occurred during a few days in summer, probably causing the displacement of sardines out of the area. During that summer fishermen reported that they were not catching sardines close to shore, but that they had to go to deeper waters to catch them. This is consistent with the displacement of common dolphins towards deep waters during the same summer.

\section{Investigation of habitat preferences}

When stratifying according to biological factors, more information on habitat preferences became available. The higher density of groups with calves nearshore could be due, at least partly, to the higher densities of small epipelagic fish in these areas. Lactating females may be concentrating on the highly nutrient prey available in this area. Striped dolphins are usually found in deep waters (Cañadas et al. 2005), and therefore it is unsurprising that mixed groups including striped dolphins occur with higher frequency where there are more chances of finding this species.

The type of behaviour in which the group was engaged when encountered also seemed to influence the selection of the habitats. The largest difference was observed between groups feeding and groups socialising. The main concentrations of small epipelagic fish, probably the main prey during daylight, are over the continental shelf and shelf edge, which is where feeding groups were encountered. The lack of observations of feeding behaviour in deep waters does not mean that common dolphins do not feed on oceanic fish or squid species, as has been reported from other parts of the world (Young \& Cockcroft 1994, 1995, Scott \& Cattanach 1998). This may occur at night, when those types of prey undergo vertical migrations towards the surface. The reasons for a higher number of groups socialising in deep waters are unclear. The fact that travelling groups have the same distribution patterns as analyses involving environmental factors only, is consistent with the fact that travelling occurs in all regions.

All models show a strong tendency for larger group sizes to occur in shallow waters around the shelf edge, and especially in the area of Southern Almería, sometimes extending westwards towards Granada. The reasons for such a clear and constant pattern are not clear. If it only occurred under certain circumstances (e.g. when feeding), then it could be suggested that there may be advantages in aggregating during feeding in these areas. But as it occurs under all circumstances, there must be other factors leading to the aggregation into large groups around the shelf edge, regardless of activity or social structure. It would be worth exploring this issue in greater depth.

A possible cause of the observed bimodality in the abundance of groups and animals with respect to depth, besides the effect of the 'intrinsic' factors, could be the wind regime, which alters the location of the 
upwellings in the Alborán Sea. The Coriolis force creates a current in the surface waters at an angle of about $45^{\circ}$ to the right of the wind direction (Medina 1974). In the Alborán Sea, the main wind regimes are either from the west ('Poniente') or from the east ('Levante'), usually blowing approximately parallel to the coast. The current created by the 'Poniente' pushes the coastal superficial waters far from the coast, creating upwellings close to the shore where the cooler and nutrient rich waters from the bottom replace the superficial waters displaced. In contrast, the 'Levante' pushes the superficial waters towards the coast, where they sink, and the upwellings are created several kilometres away from the coast. This may explain why distance from coast is often selected over depth in the models. Future work will explore how dolphin distribution is influenced by these wind regimes, taking into account possible time lags between the start of the winds, the creation of the upwellings and the possible reaction of the dolphins.

The present study has shown that introducing biological factors into the analysis leads to a clearer picture of how common dolphins use their habitat in the Alborán Sea. This not only improves our understanding of the ecology of the species, but should also lead to more effective conservation. Even so, many questions remain unanswered regarding the reasons for such patterns. Why are there systematically larger group sizes around the shelf edge, even when the animals are not feeding? Why is there always a 'gap' in intermediate waters (around 300 to $600 \mathrm{~m}$ depth) where density is lower? Why is there a larger density of groups travelling and socialising in deep waters? Why are there more but generally smaller groups in Western Alborán, and fewer but usually larger groups off Southern Almería? Why do groups with calves prefer shallower waters and groups without calves deeper waters?

\section{Changes in abundance of common dolphins over time}

The lack of trends in the abundance estimates for the northern Alborán Sea between 1992 and 2004 contrasts with the apparent decline of common dolphins in the rest of the Mediterranean Sea (Bearzi et al. 2003) and with the reported high levels of by-catch in Moroccan driftnets in the southern Alborán Sea (Tudela et al. 2005).

In contrast to the reported decline and vulnerable status of this species in the rest of the Mediterranean Sea, the common dolphins inhabiting the northern Alborán Sea appear able to maintain a relatively large and stable population. This area has particular oceanographic characteristics with very high productivity that might be able to support such a population. Further- more, common dolphins inhabiting this basin are genetically more closely related to those in the North Atlantic than to those in the rest of the Mediterranean Sea (Natoli 2005), and thus may be better considered part of the Atlantic population, rather than the Mediterranean.

Implications of reported by-catch in Moroccan
driftnets

According to Tudela et al. (2005), an estimated 1500 to 2000 common dolphins are caught every year in Moroccan driftnets in the southern Alborán Sea. Simplistically extrapolating estimated density from the northern Alborán Sea to the rest of the basin gives an abundance of around 95000 common dolphins, and the by-catch estimate would then represent about $2 \%$ of the population.

Unfortunately, there is little information on common dolphins outside our study area, and therefore any inferences about the density in the Southern Alborán Sea must be viewed with caution. Nevertheless, it seems likely that density in the southwestern portion may be relatively high because in both years of the 1991 to 1992 survey of Forcada \& Hammond (1998) there was an aggregation of sightings close to the southwestern coast of the Alborán Sea, corresponding to the southern edge of the Western anticyclonic gyre, known for its high productivity (Rodriguez 1982, Rubín et al. 1992).

The stranding records show a high presence of common dolphins along the western coast of Algeria (Boutiba 1994), corresponding with the southern end of the Almería-Orán front, where productivity is enhanced (Tintoré et al. 1988). The rest of the southern portion of the Alborán Sea is much poorer than the northern section in terms of nutrients and productivity (Parrilla \& Kinder 1987, Rubín 1994), and thus common dolphin density in these areas is likely lower than in the highly productive northern areas. However, opportunistic sightings around Melilla (coast of Morocco, south of Almería) indicate a relatively constant presence of common dolphins in these coastal waters (A. del Salto pers. comm.).

The contrast between the estimated by-catch in Tudela et al. (2005) and the lack of trend in abundance in the Alborán Sea presented here could be due to one of several factors, or to a combination of some of these factors:(1) The estimated by-catch rate comes from observations in 1 single port along the Mediterranean Moroccan coast and extrapolated to the other ports (Tudela et al. 2005). If the bycatch rate from other ports is lower than the observed port (because, for example, of differences in dolphin density and habitat use along the whole coast, and differences in fleet operations from different ports) 
then total by-catch may be overestimated; (2) There may be a population structure within the Alborán Sea, with common dolphins from the southernpart being different from those in the northern part. In this case, the by-catch could be depleting the southern 'population' and not affecting the northern one. This seems very unlikely, given the size of the basin and the high mobility of the dolphins. Genetic analysis has shown that the common dolphins in the northern Alborán Sea and the Strait of Gibraltar are not different from those in the contiguous Atlantic waters, implying an important gene flow through the strait (Natoli 2005). The same study shows, on the other hand, that these dolphins are genetically distinct from those in the central and eastern Mediterranean Sea, with limited gene flow. Unfortunately, not enough samples are available from the North African coast to explore population structure within the Alborán Sea; (3) The population is large enough (for example, density in the southern portion is higher) to sustain the by-catch, so no trend would be expected. However, we do not know population size in the whole Alborán Sea, nor the whole by-catch.

Before these questions can be answered it is necessary to survey the whole Alborán Sea, and especially along the North African coast, to yield accurate abundance estimates of this area and the basin in general. It would also be of great interest to collect and analyse samples from the southern areas to assess the genetic identity and possible population structure of the dolphins inhabiting the Alborán Sea. It is also important to continue and extend to other ports the monitoring of the by-catch along the Moroccan coast. All this information is necessary to assess the impact of by-catch (and other threats) and therefore to develop adequate and effective conservation measures.

\section{Decline in the Gulf of Vera}

One reason for the decline of common dolphin density in the Gulf of Vera may be the exponential growth of aquaculture in the area since the mid-1990s (www.carm.es). Many aquaculture farms have been developed in the region of Murcia (northern Gulf of Vera) since then for gilthead seabream Sparus aurata, European seabass Dicentrarchus labrax and especially Northern blue fin tuna Thunnus thynnus. The main species caught to feed fish in these aquaculture farms is the round sardinella Sardinella aurita. The catches of this fish, traditionally not a commercial species, went from almost 0 at the beginning of the 1990s to an average of $1700 \mathrm{t} \mathrm{yr}^{-1}$ by 2003 (www.carm.es). In the Alborán Sea, aquaculture has not yet developed to this extent, and the catches of round sardinella have remained stable at around 400 tons $\mathrm{yr}^{-1}$ in the much larger region of Andalucía (Alborán Sea and Southern Gulf of Vera) since 1985 (www.juntadeandalucia.es/ agriculturaypesca/portal/opencms/portal/portada.jsp). If common dolphins have declined in the northern Gulf of Vera because of the overexploitation of the round sardinella, on which they might be feeding there, they may have moved to deeper waters to feed on other types of prey (as they likely did in Southern Almería in 1999, and as occurs during the winter months), i.e. they may have left an area that had become less suitable for them due to declining food resources.

However, the decline in the Gulf of Vera could also be the product of other factors that have been proposed as reasons for the general decline in the rest of the Mediterranean. These factors, including pollution, by-catch, oceanographic changes, etc. are described in more detail in Bearzi et al. (2003). Even if these factors have not yet, apparently, affected the Alborán Sea dolphins to the point of producing a detectable negative trend, close monitoring should be kept on this population to be able to detect any adverse change, as well as on human activities in the area to ensure that they do not become out of control in terms of environmental impact. Sustainable fishing should be the main priority in terms of conservation of common dolphins, irrespective of the use made of catches (e.g. human consumption, aquaculture farms). For example, the control and close monitoring of aquaculture activities and their effects on the fish stocks (specially overfishing of prey species) should be part of any attempt to develop conservation measures for common dolphin, not only in this area, but in the entire Mediterranean Sea.

\section{CONCLUSIONS}

Knowledge about the distribution patterns of this species has improved substantially as a result of the work carried out during the last $14 \mathrm{yr}$ in the study area; this is an important contribution to the requirements of the ACCOBAMS common dolphin Conservation Plan, in particular to the increase in knowledge in one of the identified ACIs. Results for the Alborán Sea and the Gulf of Vera show that dolphins are using these 2 areas in a different way, even though they are geographically so close. This is likely because these areas are very different environmentally; the Gulf of Vera is hydrographically Mediterranean but the Alborán Sea is more similar to the Atlantic. We should be cautious about extrapolating our results to unsurveyed areas because the models are 'predictive' (descriptive) rather than 'explanatory', and different environmental characteristics and processes may occur elsewhere. However, the different results in the Alborán Sea and the Gulf of Vera and their different physical/environmen- 
tal characteristics suggest that exploration of similarities and differences in environmental features elsewhere in the Mediterranean may help us to understand why common dolphins have declined or redistributed to other unsurveyed areas. In particular, in some areas where coastal communities of common dolphins have declined it would be worthwhile to explore whether or not there has been a shift in distribution towards less surveyed deeper waters, as observed in the present study.

Knowledge of preferred habitats for common dolphin, especially with respect to their different needs such as feeding or reproduction, is absolutely essential for effective conservation. Knowing the areas mostly used by dolphins with calves or for feeding could lead to specific management measures for those areas, which may need special or different treatment from other areas. In this case, it seems clear that, despite the high densities of common dolphins also predicted for deep waters, the most critical areas for this species within the study area are the waters around the shelf edge, where they concentrate to feed and where the large majority of the calves are encountered. Unfortunately, this is also the area with the strongest impact from human activities: pollution from land sources, overfishing and disturbance by the intense maritime traffic of small to medium size ships. The continental shelf and shelf edge of the Alborán Sea are vulnerable in 2 ways: this is where the common dolphin population seems to be more vulnerable (feeding and calving grounds), and also where the marine environment is more vulnerable (stronger human impact). Notwithstanding attempts to develop management strategies for the whole Alborán Sea, when considering possible MPAs within the Alborán Sea ACI, priority should be given to the conservation or restoration of the marine environment from the coast up to beyond the shelf edge (e.g. up to 400 to $500 \mathrm{~m}$ depth) if conservation of the common dolphin population is to be achieved.

Acknowledgements. We are very grateful to all the people who helped with data collection, especially the Earthwatch volunteers and the Alnitak and SEC (Sociedad Española de Cetáceos) staff R. Sagarminaga, M. Ovando, J. A. Fayos, S. García-Tiscar, M. Padilla and P. Marcos, and with data analysis, especially L. Thomas, M. Lonergan and S. Hedley. Special thanks to J. A. Vázquez for coordinating data collection on board the RV 'Else'. The reviewers provided valuable comments and suggestions for improvement. The CREPAD service of the INTA (Spanish Space Agency) provided the satellite images of sea surface temperature. The International Fund for Animal Welfare (IFAW) provided the data logging software Logger. This work was funded by Alnitak from 1995 to 1999, the Spanish Ministry for the Environment from 2000 to 2002, and the European Commission (LIFE02NAT/E/8610) from 2003 to 2006. The Earthwatch Institute has co-funded the work since 1999.

\section{LITERATURE CITED}

Abad R, Giráldez A, Crespo J (1987) Relación entre caladeros tradicionales de sardina (Sardina pilchardus) y resultados de campañas de bioacústica en la región surmediterránea española. FAO Rapp Pêches 395:57-60

ACCOBAMS (2002) Proceedings of the first session of the meeting of the parties of the Agreement on the Conservation of Cetaceans of the Black Sea, Mediterranean Sea and Contiguous Atlantic Area (ACCOBAMS). 28 February to 2 March 2002, Monaco

Aguilar A, Forcada J, Borrell A, Silvani L and others (1994) Inventario de cetáceos mediterráneos ibéricos: status y problemas de conservación. Final project report, University of Barcelona, Spain. Available at: www.mma.es/ secciones/biodiversidad/biodiversidad_marina/inventarios_marina/inventario_nacional/medit_indice.htm

Allain G, Petitgas P, Lazure P (2001) The influence of mesoscale ocean processes on anchovy (Engraulis encrausicoulus) recruitment in the Bay of Biscay estimated with a three-dimensional hydrodynamic mode. Fish Oceanogr 10:151-163

> Bearzi G, Reeves RR, Notarbartolo di Sciara G, Politi E, Cañadas A, Frantzis A, Mussi B (2003) Ecology, status and conservation of short-beaked common dolphins Delphinus delphis in the Mediterranean Sea. Mammal Rev 33: 224-252

Bearzi G, Notarbartolo di Sciara G, Reeves RR, Cañadas A, Frantzis A (2004) Conservation plan for short beaked common dolphins in the Mediterranean Sea. Agreement on the Conservation of Cetaceans of the Black Sea, Mediteranean Sea and Contiguous Atlantic Area (ACCOBAMS), Monaco

Borchers DL, Burt ML (2001) Generalized regression methods for estimating school size from line transect data. Paper SC/54/IA23 presented to the Scientific Committee of the International Whaling Commission (IWC), May 2002. IWC Cambridge

Borchers DL, Buckland ST, Zucchini W (2002) Estimating animal abundance. Closed populations. Springer, London

Borja A, Uriarte A, Egaña J, Motos L, Valencia V (1998) Relationships between anchovy (Engraulis encrausicoulus) recruitment and environment in the Bay of Biscay (1967-1976). Fish Oceanogr 7:375-380

Boutiba Z (1994) Bilan de nos connaissances sur la présence des cétacés le long des côtes algériennes. Mammalia 58:613-622

Brereton T, Williams A, Martin C (2005) Ecology and status of the common dolphin Delphinus delphis in the English Channel and Bay of Biscay 1995-2002. Stockin K, Vella A, Evans $\mathrm{P}$ (eds) Proceedings of the workshop on common dolphins: current research, threats and issues. Kolmarden, Sweden, 1 April, 2004. Spec Issue April 2005, Kolmarden, p 15-22

Buckland ST, Anderson DR, Burnham KP, Laake JL, Borchers DL, Thomas L (2001) Introduction to distance sampling. Estimating abundance of biological population. Oxford University Press, Oxford

Cañadas A, Hammond PS (2006) Model-based abundance estimates for bottlenose dolphins off Southern Spain: implications for conservation and management. J Cetacean Res Manag 8:13-27

Cañadas A, Sagarminaga R, García-Tiscar S (2002) Cetacean distribution related with depth and slope in the Mediterranean waters off southern Spain. Deep-Sea Res I 49: 2053-2073

Cañadas A, Desportes G, Borchers DL (2004) Estimation of $\mathrm{g}(0)$ and abundance of common dolphins (Delphinus del- 
phis) from the NASS-95 Faroese survey. J Cetacean Res Manag 6:191-198

Cañadas A, Sagarminaga R, de Stephanis R, Urquiola E, Hammond PS (2005) Habitat selection modelling as a conservation tool: proposals for marine protected areas for cetaceans in southern Spain. Aquat Conserv: Mar Freshw Ecosyst 15:495-521

Cañadas A, Donovan G, Desportes G, Borchers D (in press) Distribution and abundance of short-beaked common dolphins (Delphinus delphis) in the central and eastern North Atlantic. North Atlantic Marine Mammal Commission (NAMMCO) Scientific Publications Vol 7, Tromsø

Cordeiro M (1996) Contribuição para o conhecimento do regime alimentar e da biologia da reprodução do golfinhocomum, Delphinus delphis Linnaeus, 1758, na costa Portuguesa. Masters thesis, University of Lisbon

Díaz del Río V (1991) El Margen Continental Bético Mediterráneo. Extremo Bético Oriental: Cuenca de Murcia Escarpe de Mazarrón. Publ Espec Inst Esp Oceanogr 6

Ferretti S (1999) Respiration pattern of common dolphins and bottlenose dolphins in Ionian Greece coastal waters. MSc thesis, University of Milan

Forcada J, Hammond P (1998) Geographical variation in abundance of striped and common dolphins of the western Mediterranean. J Sea Res 68:1-13

Gannier A 1995. Les cétacés de Méditerranée nord-occidentale: estimation de leur abondance et mise en relation de la variation saisonnière de leur distribution avec l'écologie du milieu. PhD thesis, Ecole Pratique des Hautes Etudes, Montpellier

Gascard JC, Richez C (1985) Water masses and circulation in the western Alborán Sea and in the Straits of Gibraltar. Prog Oceanogr 15:157-216

Gil J (1992) Consideraciones sobre el hábitat medioambiental de los cardúmenes de sardina en la plataforma continental mediterránea y Golfo de León. Informe Técnico Especial del Instituto Español de Oceanografía 114

Hammond PS, Berggren P, Benke H, Borchers DL and others (2002) Abundance of harbour porpoise and other cetaceans in the North Sea and adjacent waters. J Appl Ecol 39:361-376

Hedley SH, Buckland ST, Borchers DL (1999) Spatial modelling from line transect data. J Cetacean Res Manag $1: 255-264$

Hiby AR (1982) The effect of random whale movement on density estimates obtained from whale sighting surveys. Rep Int Whaling Comm 32:791-794

Horvitz DG, Thompson DJ (1952) A generalisation of sampling without replacement from a finite universe. J Am Stat Assoc 47:663-685

Kenney RD, Scott GP, Thompson TJ, Winn HE (1995) Estimates of prey consumption and trophic impacts of cetaceans in the USA northeast continental shelf ecosystem. J Northw Atl Fish Sci 22:155-171

Klinowska MM (1991) Dolphins, porpoises and whales of the world. The IUCN red data book. IUCN, Cambridge and Gland

Lotina R (1985a) Anatomía, fisiología y nutrición de la sardina. In: La sardina, un tesoro de nuestro mar. Fondo de Regulación y Organización del Mercado de los Productos de la Pesca y Cultivos Marinos, Ministerio de Agricultura y Pesca, Lunwerg Editores, Madrid

Lotina R (1985b) Biología, geografía y hábitat de las sardinas ibéricas. In: La sardina, un tesoro de nuestro mar. Fondo de Regulación y Organización del Mercado de los Productos de la Pesca y Cultivos Marinos, Ministerio de Agricultura y Pesca, Lunwerg Editores, Madrid
MacNally R (2000) Regression and model-building in conservation biology, biogeography and ecology: the distinction between - and reconciliation of - 'predictive' and 'explanatory' models. Biodivers Conserv 9:655-671

Marques FFC (2001) Estimating wildlife distribution and abundance from line transect surveys conducted from platforms of opportunity. PhD thesis, University of St. Andrews

Medina M (1974) La mar y el tiempo. Ed. Juventud, Barcelona

Millot C (1985) Some features of the Algerian current. J Geophys Res 90(C4):7169-7176

Natoli A (2005) Molecular ecology of bottlenose (Tursiops sp.) and common (Delphinus sp.) dolphins. PhD thesis, University of Durham

Natoli A, Cañadas A, Vaquero C, Politi P, Fernández-Piqueras J, Hoelzel AR (2008) Conservation genetics of the shortbeaked common dolphin (Delphinus delphis) in the Mediterranean Sea and in the eastern North Atlantic Ocean. Conserv Genet doi:10.1007/s10592-007-9481-1

Neumann DR (2001a) Seasonal movements of short-beaked common dolphins (Delphinus delphis) in the north-western Bay of Plenty, New Zealand: influence of sea surface temperature and El Niño/La Niña. NZ J Mar Freshw Res 35:371-374

Neumann DR (2001b) The activity budget of free-ranging common dolphins (Delphinus delphis) in the northwestern Bay of Plenty, New Zealand. Aquat Mamm 27:121-136

Northridge SA Mackay, Sanderson D, Woodcock R, Kingston A (2004) A review of dolphin and porpoise bycatch issues in the southwest of England. An occasional report to the Department for Environment, Food and Rural Affairs, Sea Mammal Research Unit. Available at: Sea Mammal Research Unit, Gatty Marine Laboratory, St Andrews

Ó Cadhla O, Mackey M, Aguilar de Soto N, Rogan E, Connolly N (2003) Cetaceans and seabirds of Ireland's Atlantic margin. II. Cetacean distribution \& abundance. Report on research conducted under the 1997 Irish Petroleum Infrastructure Programme (PIP): Rockall Studies Group (RSG), projects 98/6 and 00/13, Porcupine Studies Group project P00/15 and Offshore Support Group (OSG) project 99/38, University College Cork

Palka DL, Hammond PS (2001) Accounting for responsive movement in line transect estimates of abundance. Can J Fish Aquat Sci 58:777-787

Parrilla G, Kinder TH (1987) Oceanografía física del mar de Alborán. Bol Inst Español Oceanogr 4:133-165

Pollock C, Reid J, Webb A, Tasker M (1997) The distribution of seabirds and cetaceans in the waters around Ireland. JNCC Report No. 267 Joint Nature Conservancy Council, Peterborough

Reeves RR, Smith BD, Crespo EA, Notarbartolo di Sciara G (compilers) (2003) Dolphins, whales and porpoises: 2002-2010 Conservation Action Plan for the World's Cetaceans. IUCN/SSC Cetacean Specialist Group. IUCN, Gland and Cambridge

Rodriguez J (1982) Oceanografía del mar Mediterráneo. Ed. Pirámide, Madrid

Rodríguez V, Blanco JM, Echeverría F, Rodríguez J, JiménezGómez F, Bautista B (1994) Nutrientes, fitoplancton, bacterias y material particulado del mar de Alborán, en julio de 1992. Informe Técnico del Instituto Español de Oceanografía 146:53-77

Rubín J P (1994) El ictioplacton y el medio marino en los sectores norte y sur del mar de Alborán, en junio de 1992. Informe Técnico del Instituto Español de Oceanografía 146, Madrid 
Rubín JP, Gil J, Ruiz J, Cortés MD, Jiménez-Gómez F, Parada M, Rodriguez J 1992. La distribución ictioplanctónica y su relación con parámetros físicos, químicos y biológicos en el sector norte del Mar de Alborán, en julio de 1991 (Resultados de la Campaña 'Ictio.Alborán 0791'). Informe Técnico del Instituto Español de Oceanografía. 139, Madrid

Santos M B, Pierce GJ, López A, Barreiro A, Guerra A (1996) Diets of small cetaceans stranded in NW Spain. Int Counc Explor Sea 11. Marine mammal Committee.

Scott MD, Cattanach KL (1998) Diel patterns in aggregations of pelagic dolphins and tunas in the Eastern Pacific. Mar Mamm Sci 14:401-428

Seber GAF (1982) The estimation of animal abundance and related parameters. MacMillan, New York

Thomas L, Buckland ST, Burnham KP, Anderson DR, Laake JL, Borchers DL, Strindberg S (2002) Distance sampling. In ElShaarawi AH, Piegorsch WW (eds) Encyclopedia of environmetrics. John Wiley \& Sons, Chinchester, p 544-552

Thomas L, Laake JL, Strindberg S, Marques FFC and others (2005) Distance 5.0. Release 5.1. Research Unit for Wildlife Population Assessment, University of St. Andrews. Available at: www.ruwpa.st-and.ac.uk/distance/

Tintoré J, La Violette PE, Blade I, Cruzado A (1988) A study of an intense density front in the eastern Alboran Sea: the Almería-Oran front. J Phys Oceanogr 18(10):1384-1397

Tudela S, Kai Kai A, Maynou F, El Andalossi M, Guglielmi P (2005) Driftnet fishing and biodiversity conservation: the

Editorial responsibility: Brendan Godley,

University of Exeter, Cornwall Campus, UK case study of the large-scale Moroccan driftnet fleet operating in the Alborán Sea (SW Mediterranean). Biol Conserv 121:65-78

UNEP (United Nations Envronment Programme)/IUCN (1994) Technical report on the state of cetaceans in the Mediterranean. Mediterranean Action Plan Technical Reports Series No. 82, UNEP, Regional Activity Centre for Specially Protected Areas, Tunis

Universidad de Barcelona (2002) Programa para la identificación de las áreas de especial interés para la conservación de cetáceos en el Mediterráneo español. Vol II. Sector Norte. Dirección General de Conservación de la Naturaleza, Ministerio de Medio Ambiente, Madrid

Universidad de Valencia (2002) Programa para la identificación de las áreas de especial interés para la conservación de cetáceos en el Mediterráneo español. Vol I. Sector Centro. Dirección General de Conservación de la Naturaleza, Ministerio de Medio Ambiente, Madrid

Wood SN (2001) mgcv: GAMs and generalized ridge regression for R. R News 1(2):20-25.

Young DD, Cockcroft VG (1994) Diet of common dolphins (Delphinus delphis) off the south-east coast of southern Africa: opportunism or specialization? J Zool 234:41-53

Young DD, Cockcroft VG (1995) Stomach contents of stranded common dolphins Delphinus delphis from the south-east of Southern Africa. Z Saugetierkd 60: $343-351$

Submitted: May 28, 2007; Accepted: November 5, 2007 Proofs received from author(s): March 14, 2008 